NBER WORKING PAPER SERIES

\title{
DOES ELECTRICITY DRIVE STRUCTURAL TRANSFORMATION? EVIDENCE FROM THE UNITED STATES
}

\author{
Paul Gaggl \\ Rowena Gray \\ Ioana Marinescu \\ Miguel Morin \\ Working Paper 26477 \\ http://www.nber.org/papers/w26477 \\ NATIONAL BUREAU OF ECONOMIC RESEARCH \\ 1050 Massachusetts Avenue \\ Cambridge, MA 02138 \\ November 2019
}

Gray and Morin gratefully acknowledge the financial support of the Russell Sage Foundation (grant 85-15-12). The views expressed herein are those of the authors and do not necessarily reflect the views of the National Bureau of Economic Research.

NBER working papers are circulated for discussion and comment purposes. They have not been peer-reviewed or been subject to the review by the NBER Board of Directors that accompanies official NBER publications.

(C) 2019 by Paul Gaggl, Rowena Gray, Ioana Marinescu, and Miguel Morin. All rights reserved. Short sections of text, not to exceed two paragraphs, may be quoted without explicit permission provided that full credit, including $\left({ }^{\circ}\right.$ notice, is given to the source. 
Does Electricity Drive Structural Transformation? Evidence from the United States

Paul Gaggl, Rowena Gray, Ioana Marinescu, and Miguel Morin

NBER Working Paper No. 26477

November 2019

JEL No. E24,J24,N32,N72,O33

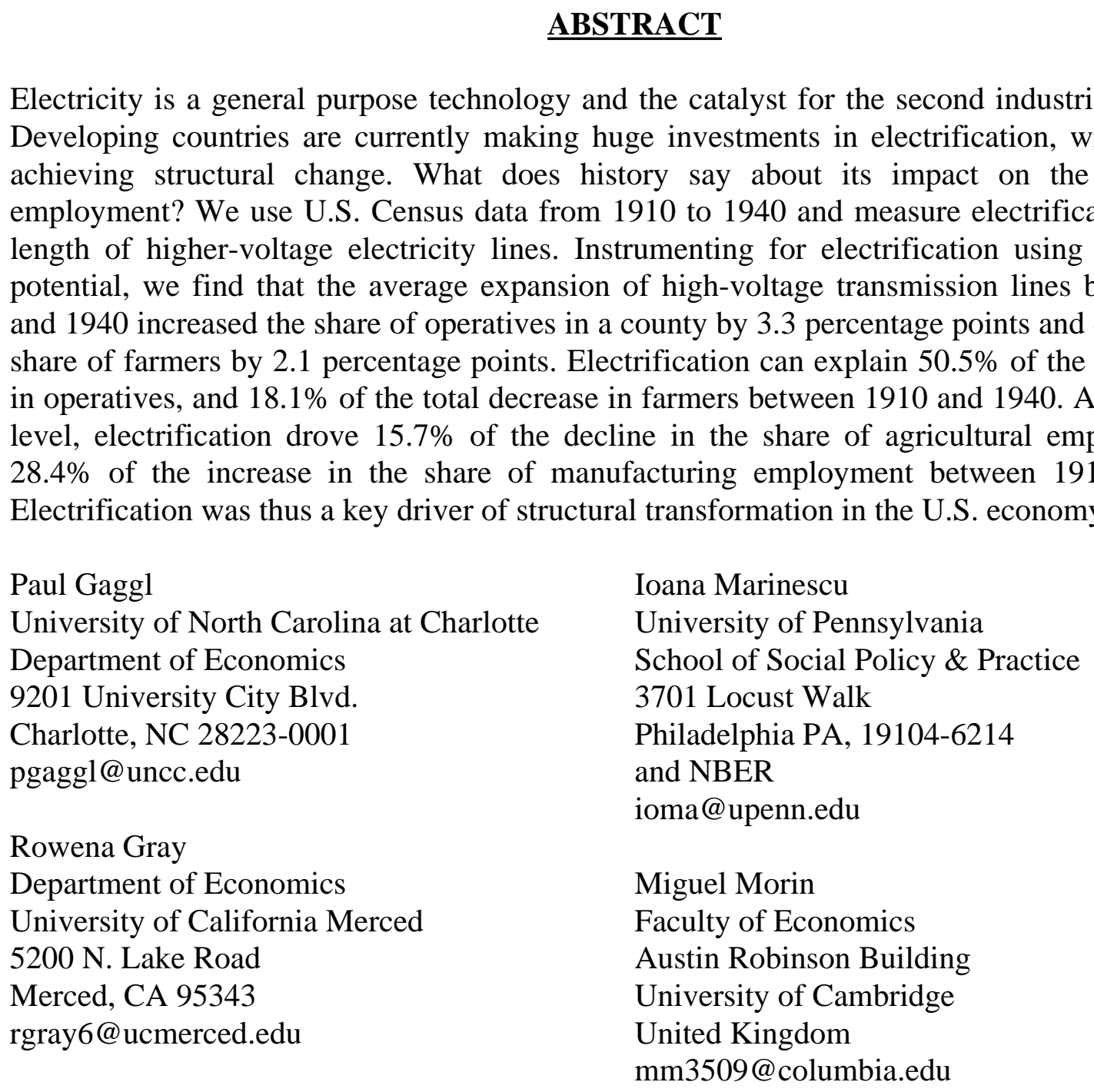




\section{Introduction}

For the first time in U.S. history, the federal Census in 1920 reported more than $50 \%$ of residents living in urban areas, marking a turning point in a long movement off farms and towards cities, with the accompanying transition to urban occupations and industries. In fact, Figure 1 illustrates a massive labor reallocation over the period 1910-1940, from agricultural occupations toward ones more concentrated in sectors such as manufacturing, retail, and wholesale trade. This structural transformation was achieved relatively late in the U.S., due to its status as a young nation and a destination for individuals seeking to make their fortunes on the land. The backdrop of this transformation was an equally dramatic transformation of infrastructure, involving the move from steam to electric power in cities and from horse to electric power in rural areas. While this kind of structural transformation is one of the most salient features of economic development (Herrendorf, Rogerson and Valentinyi, 2014)—identified as one of Kuznets' stylized facts of development (Kuznets, 1966)—-there is still considerable debate about its underlying causes.

Historical studies have focused on explaining the transition from an agriculture-based economy to one where manufacturing is the dominant sector, while more recent studies also seek to explain later stages of development when manufacturing is now on the wane and services becomes dominant for richer countries. Gollin, Jedwab, Vollrath et al. (2013) provide a nice summary of the theoretical literature on structural change, from theories that focus on the increased productivity of manufacturing and services, which creates a "pull" force for labor to move out of agriculture, and the "push" theories which investigate the price and income effects influencing the move away from the primary sector. ${ }^{2}$

This paper focuses on the specific role played by electrification, a general purpose technology that drove the second industrial revolution in the developed world (Gordon, 2017) and still plays a crucial role for economic development today. ${ }^{3}$ Many developing countries are currently witnessing unprecedented investment in electrification as a vehicle for development, in the hope that it will stimulate structural transformation, pushing more workers into modern, higher valued-added sectors. In fact, the World Bank argues that "infrastructure has a central role in the development agenda and is a major contributor to growth" (World Bank,

\footnotetext{
${ }^{2}$ On the latter types of models, see, for example, Herrendorf, Rogerson and Valentinyi (2013). Other creative explanations for the new dominance of the service sector include, for instance, Cravino, Levchenko and Rojas (2019) which suggests that this is a natural result of the aging of populations in the developed world.

${ }^{3}$ Gordon (2017) showed that the second industrial revolution was sparked by the perfection of the steam engine but realized such high productivity gains due to electricity. So far, the gains from the second industrial revolution dwarf those of the third.
} 
Figure 1: Approximate Contribution of Electrification to Structural Transformation

(A) Occupations

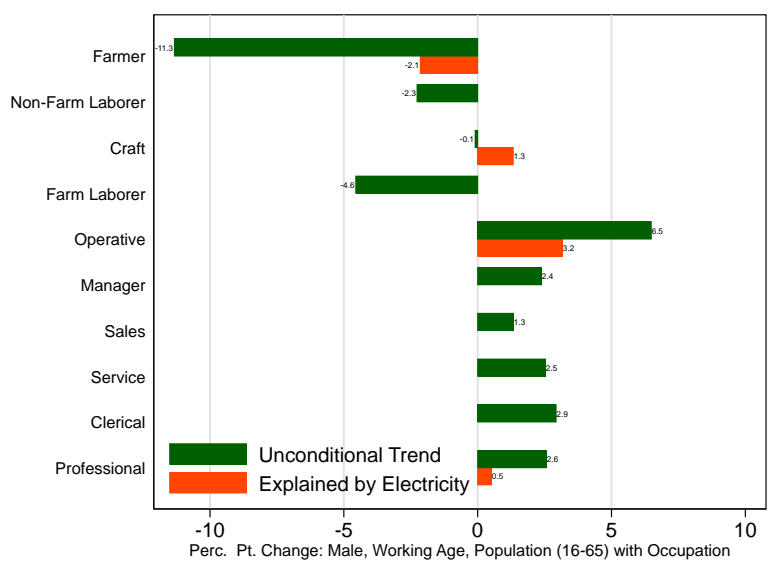

(B) Industries

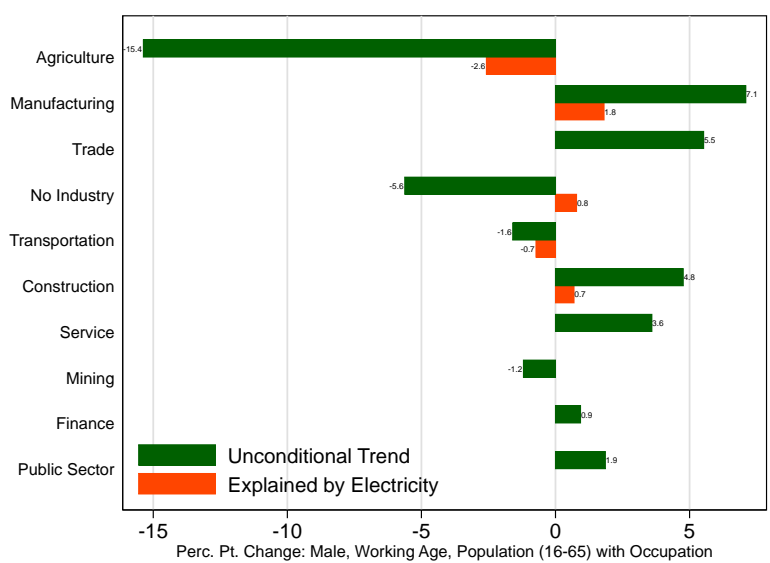

Notes: The figure depicts overall changes in the occupational structure as displayed in Figure 3 and contrasts them with the structural changes due to electrification as implied by our IV estimates (Tables 5 and 7) scaled by the average increase in transmission lines within a county (Table 2). Panel A focuses on occupations while panel B reports our results for industries. We only report implied IV estimates for statistically significant coefficients. The underlying data on the occupational and industrial structure are the full count U.S. Cenuses for the years 1910, 1920, 1930, and 1940. The impact of electrification is estimated using historical maps of the U.S. electricity grid and hydroelectric potential as an instrument. Details are provided in Sections 3 and 4.

2005) and states that it has helped 45 million people to gain access to electricity from 2014 to 2018 and spent over $\$ 5$ billion on energy programs. ${ }^{4}$ Ethiopia is a leading example of a developing nation recently investing heavily in electricity. Fried and Lagakos (2017) analyze the extent to which this investment translated into structural change and find an increase in non-agricultural businesses in rural areas, mostly in retail and wholesale trade rather than manufacturing.

In this paper, we present the first quantification (to our knowledge) of the contribution of electrification to U.S. structural change, focusing on the years 1910 to 1940 and utilizing a dataset that allows us to look across the universe of geographies, occupations and industries. Looking at this historical episode allows us to analyze the long run impacts of electrification over three decades (1910-1940), which is generally not possible in the modern development literature but is important given the lengthy time general purpose technologies usually need to unfold their full potential through complementary innovations. ${ }^{5}$ Examining the impact of this earlier major general purpose technology on the labor market over the long run can also allow

\footnotetext{
${ }^{4}$ https://www.worldbank.org/en/topic/energy/overview\#2. Consulted: 10/13/19.

${ }^{5}$ See, for example, Rud (2012); Burlig and Preonas (2016), which look at most over two decades interval to analyze the effects of electrification in India, and Fried and Lagakos (2017), who look at the period since 2012 because Ethiopia's electrification is so recent.
} 
us to gain insights on the potential impacts of the most recent general purpose technology, information and communication technologies (ICT).

One serious challenge in estimating the impact of electrification is that the proliferation of electricity is likely endogenous to existing levels of development, available local skills and industrial composition. To address this concern, we use hydro-electric potential within 50 miles of a county to instrument for electrification, as proxied by the length of high-voltage power lines in a county. Hydro-electric potential is high for areas that have sufficient flows of water that can fall from sufficient heights-in other words, exogenous geographic endowments. We investigate the impact of 1910-1940 electrification on the occupational and industrial structure of male county employment in 1940, controlling for initial 1910 conditions in each county. Using this IV, we find that 100 extra kilometers of high-voltage power lines significantly decreased the share of farmers among American men, and significantly increased the share of operatives. In parallel, electrification significantly decreased the share of farming in male employment and increased the share of manufacturing. The size of the effects implies that electrification can explain $50.5 \%$ of the increase in the share of operatives, and $24.8 \%$ of the decline in the share of farmers between 1910 and 1940 . As for the industrial structure, electrification can account for $15.7 \%$ of the decline in agriculture and $28.4 \%$ of the increase in manufacturing. Figure 1 graphically illustrates these results and highlights that electrification is thus a key driver of structural transformation.

Additional results show that more than half of the impact of electrification on the share of operatives was already visible in 1930 while the negative impact of electrification on farmers only becomes significant in 1940. Furthermore, the increase in the share of operatives entirely occurred in counties that were rural in 1910 rather than in urban counties. This highlights how important a role electrification plays in transforming economic activity in rural areas.

Our analysis makes three key contributions to the literature. First, we provide a credible instrument for the expansion of the high-voltage power grid in order to investigate the causal impact of electrification on structural transformation at the early stages of economic development in the U.S.. Specifically, we use a measure of "hydro-electric potential", which is governed by fixed, exogenous topographic characteristics of a place, which is related to the cost of building and operating a hydro-electric power station in any given location. In doing so, we are building on U.S. literature that used the distance to power plants (Lewis and Severnini, 2017) as an instrument, and a literature that directly looked at how hydro-electric potential 
affected agglomeration economies in different areas (Severnini, 2014).

Second, we study the impact of electrification on the entire U.S. territory, examining effects on the occupational and industrial structure of employment. We digitized historical maps to document the expansion of the high-voltage electricity grid within the contiguous U.S. states. We argue that the expansion of the high-voltage electricity grid serves as a proxy for the proliferation of hydro-electric power, and we are able to use this measure thanks to our digitization of new data from the U.S. Army Corps of Engineers. This provides us with a nationwide source of variation for electricity adoption due to the invention of high-voltage power transmission - a general purpose technology shock. Previous studies of the impact of electrification in the U.S. analyze either the manufacturing sector, using the Census of Manufacturers (Gray, 2013), or the agricultural sector (Census of Agriculture) in isolation (Kitchens and Fishback, 2015), and some focus on programs that were only applicable in a few states. Ours is the first attempt to use detailed exogenous variation in electricity adoption to study potential labor re-allocation between, rather than within sectors. Furthermore, because we use full Census data, we go beyond just agriculture and manufacturing and analyze the impact of electrification on the full occupational and industrial structure. We thus complement the work by Katz and Margo (2014), which focused on skill bias rather than structural transformation and did not use an instrument for electrification.

Third, the extant literature on structural transformation offers a variety of theoretical explanations for its ultimate causes. One class of models draws on dominant income effects (through non-homothetic preferences) while another class of models draws on a production structure in which general purpose technology shocks - through a reduction in the relative price—have differential effects in different sectors (Herrendorf et al., 2014). Our analysis provides evidence that the invention of high-voltage electrical power transmission - a general purpose technology—directly caused structural transformation of rural America during the period 1910-1940, consistent with the theory of technology-driven structural transformation.

Probably most closely related to this paper is Bustos, Caprettini and Ponticelli (2016) which explores the impact of two agricultural innovations on structural transformation in Brazil. They find that one of their technologies is labor-saving and it has the clear effect of reallocating labor from agriculture to manufacturing, which impacted more intensely areas suited more to crops using this technology. Our case is slightly different because we deal with a general purpose technology which had a variety of effects across all sectors and places, and we discuss those effects in the next section. They also add a services sector to their model 
and suggest that, as incomes rise, more is devoted to non-tradable services. While services is not the focus of this paper, we note that the employment shares of service-related occupations, such as professions, sales and distribution did grow during our period.

In section 2, we discuss the role electricity could play in the occupational and industrial composition of employment. In section 3, we describe the data and our econometric specification. In section 4, we present the results. Finally, section 5 concludes.

\section{What did electricity do?}

This section does not present a formal model but is intended to provide a conceptual framework to inform our empirical analysis below.

Electricity, as with many general purpose technologies, took a very long time to bring large productivity gains to all sectors of the U.S. economy, from the realization of commercial viability of the technology in the 1880s through to 1960, by which time rural electrification was complete. We know from existing research that it had large productivity effects—David and Wright (1999) showed that electricity contributed about half of the five-fold increase in TFP growth during the 1920s. The earliest gains were, of course, in the manufacturing sector, concentrated in large and medium-sized cities. A range of studies have analyzed the impact of electrification within manufacturing, and a more detailed summary of which can be found in Gray and Kitchens (2018). The most recent contributions are firstly Gray (2013) which showed that electrification in U.S. manufacturing led to a hollowing out of the skill distribution, whereby workers occupying jobs in the middle of the skill distribution (with craft skills) lost out to those at the poles who were mainly clerical/managerial and manual workers. A more general study was conducted by Katz and Margo (2014) which confirmed the hollowing out result for manufacturing but found that, in the economy as a whole, electricity led to skill bias, i.e. more demand for high-skilled workers. ${ }^{6}$ This is the only other paper that looks across all sectors of the national economy as it presents a description of the occupational composition of the entire labor force up to 2010.

How did electricity bring about these changes within manufacturing and usher in the era of capital-skill

\footnotetext{
${ }^{6}$ Goldin and Katz (1998) had also argued that manufacturing technology was skill-biased, because the education level of workers was correlated with electricity adoption.
} 
complementarity, as claimed by Goldin and Katz (1998)? Electricity was complementary to technologies such as the assembly line, and the bundle of new technologies led to an increased scale of production as factories were no longer limited by the capacity of inefficient steam engines. This brought increased productivity and an increased demand for clerical and managerial tasks within factories, and on the factory floor a huge increase in demand for operatives who could operate side by side in the new continuous processing mode. Where previously there had been a huge demand for high-skilled craft workers with knowledge of producing each item from start to finish, now operatives, assisted by new capital goods, dominated factory floors that were redesigned to minimize the floor space of each station and maximize efficiency, rather than accommodating the quirks of the previous steam-based system.

Rural electrification took place later and did increase agricultural productivity, looking at the Kitchens and Fishback (2015) estimates of increased crop output and yields as a result of the Rural Electrification Administration (REA) program during the 1930s. Early on, farms utilized generators for lighting and were often able to run power tools or small appliances from their cars and trucks. Purchased grid electricity replaced these smaller-scale, less convenient alternatives. Electricity on farms removed the drudgery of drawing water from the list of daily chores and facilitated the introduction of complementary technologies such as milking machines, chicken brooders, irrigation systems as well as household appliances such as washing machines and telephones. Farms in this era adopted more capital and, as in manufacturing, this may have changed the optimal scale of farming and the mix of labor, energy and capital.

Electricity thus increased employment in manufacturing, as shown by Alexopoulos and Cohen (2016), who also showed that labor turnover increased as a result. It changed the composition of tasks demanded within manufacturing and we would expect demand for semi-skilled operatives to have increased most. Within agriculture, we would expect electricity to increase the amenities available on farms as well as agricultural productivity. Such amenities include running water, refrigerators and radios, and their usage did increase in rural areas even before 1940. Those initially living in rural areas thus may have faced competing forces of the pull towards urban manufacturing amid higher farm productivity. Lewis and Severnini (2017) weighed these issues in their study of the effects of rural electrification from 1930 to 1960 and found that over that span electricity was a countervailing force in the broader decline of farm population, but that increased productivity translated into greater amenities for farm households rather than increased incomes/wages. Kline and Moretti (2013) also found gains in agricultural employment due to the TVA program, but counties 
benefiting from the program also saw increased manufacturing employment. The theoretical literature on structural change has pointed out that the effects of increasing agricultural productivity should be different in open versus closed economies. The U.S. during our sample period was mostly closed, and so the likely impact of higher agricultural productivity is to shift labor into manufacturing (Laitner, 2000) because of the higher demand for manufactured goods due to Engel's Law.

For our period, we do not have comprehensive data on wages in manufacturing/urban jobs and how those changed over time, but the existing evidence suggests that manufacturing wages rose faster than rural wages and farm incomes. Farm incomes famously suffered even before the Great Depression and continued to face downward pressure during the 1930s_-data from the U.S. Department of Commerce showed average net farm income as fairly stagnant between 1915 and 1930, but with huge fluctuations on a year-to-year basis, particularly during the 1930s (Kline, 2000, 285). Alston and Hatton (1991) presented data from 1925 to 1941 which showed that the collapse of agricultural laborer wages relative to those of manufacturing laborers started in the early 1930s. Workers who had been agricultural laborers and became manufacturing laborers or operatives were moving up the socioeconomic ladder in terms of well-being and this is likely true for many of the farmers too, since they were the ones with marginal farms that they decided to leave in favor of the manufacturing sector. It is difficult to conclude whether they moved up in terms of occupational status, as they left somewhat stable jobs with some autonomy to work in the high-turnover manufacturing sector where they would enter on a low rung of the job ladder, as manual workers or operatives.

Since our analysis ends at 1940, we conjecture that the pull into manufacturing jobs was greater than the push away from agriculture as a result of electrification. Other factors had started the long run decline of employment in agriculture from the 1910s onwards ${ }^{7}$, but the sector was only $33 \%$ electrified by 1940 (Kline, 2000, 287), so it is likely that electricity had not yet enacted substantial changes on American farms_indeed the farm population fell at a faster rate from 1940 to 1960 than it had from 1915 to 1940.

\footnotetext{
${ }^{7}$ Appendix Table A.1 in Kline (2000) shows that the U.S. farm population declined from 1915, with only a brief blip back upward in the 1930s as people reverted to subsistence on farms during the Great Depression. The number of farms followed this same pattern.
} 


\section{Data and econometric specification}

We draw from three main data sources, which we describe in detail below: first, we construct a new measure of electrification based on historical maps of the U.S. electricity grid; second, we use a measure of "hydroelectric potential" as a source of exogenous variation in the expansion of the high voltage power grid; third, we draw on the full count census of population for the years 1910-1940.

\subsection{Expansion of the U.S. Electric Grid (U.S. Army Corps of Engineers)}

AC power became the dominant power system in the U.S. from the 1890s, paving the way, with some further innovations, to longer distance power transmission from the 1920s on. City residential and commercial customers gained access to electricity from the 1880s onwards and were highly electrified by 1920. The Censuses of Manufactures show that, at the national level, electric power was more than half of total power used by 1920, overtaking steam power, and by 1930 it was over $80 \%$ of total power (Gray, 2013, Figure 1). Early urban electrification was achieved mainly by private utilities and private action by large manufacturers, with a more limited role for municipal-owned plants. Most of this power was derived from coal-burning plants, unless there was easy access to hydro-electric capability, such as at Niagara, the site of the first hydro-plant in 1881. Coal plants had the advantage of being built close to the point of use and there was some improvement in the efficiency of these large plants over our period.

For rural counties, they remained mostly without electricity by 1930, and in many places the first moves towards electrification were initiated by the government. The earliest adopters were farms in California and the southwest, where the need for irrigation motivated the choice to electrify, perhaps facilitated at least for California by the availability of hydro-electric power. Kitchens and Fishback (2015), Kline and Moretti (2013) and Kitchens (2014) document several New Deal programs such as the REA, which provided loans for farms to connect to the grid, provided that they were within a certain distance of the existing grid and the Tennessee Valley Authority, which created a series of government-built water and hydro-electric infrastructure projects from 1933. These are all towards the end of our sample period, so most of our grid expansion does not reflect these efforts. For example, the REA reported 267,846 miles of lines energized by 1940, servicing 674,495 customers (Kline, 2000, 290). This is not a small number for rural America but is still not the main story in our sample period. 
Using standard GIS software, we digitized maps compiled in 1962 by the U.S. Army Corps of Engineers, which document the expansion of the U.S. electric grid over time, and are the most detailed information used to date on access to electricity across the U.S.. We map both plant location and the expanding network of transmission lines over time (we do not have the smaller substations and distribution lines in our grid) at a finer level of geography than has previously been possible, because our maps are more detailed than those of the Edison Electric Institute, for example. As an example, panel A of Figure 2 graphically illustrates the resulting county-level exposure to the high voltage power grid in 1940, as measured by the total kilometers of high-voltage power lines within the county.

\subsection{Hydro-electric Potential (Idaho National Laboratory)}

As it is our goal estimate the causal impact of the high-voltage electricity grid expansion on the structure of the labor market, we exploit arguably exogenous variation based on "hydroelectric potential"- the potential amount of hydroelectric energy that could be generated in a given location, if a hydroelectric power station were installed. This measure is available nation wide, based on a 10 -year data collection effort by the Idaho National Laboratory (Conner and Francfort, 1998), and captures information on land gradient and stream flow across 5677 sites. We do this to exploit purely cost-driven variation in electricity across space. Panel B of Figure 2 graphically illustrates the regional distribution of hydroelectric potential. We note that the data collection effort was undertaken in the 1990s, and many locations with high hydropotential had a power station in place at that time. For such locations, the actual power generation at the plant is assumed to capture the potential before the power station was installed. Thus, from the perspective of 1910, when only a handful of locations already had a hydroelectric power station in place (that may itself have been expanded in later years), the map compiled in 1998 captures the potential power generation, if the 5677 surveyed sites were to be developed in the future.

The marginal cost of electricity was lower for hydro-electric power, but it had the twin disadvantages of high fixed costs and having to be located wherever geography provided steep enough gradients and sufficient water flow. In other words, the location of hydro-electric power will be closely linked to hydro-electric potential and to lower electricity costs. Severnini (2014) showed that this local cost advantage disappeared after 1950, when higher voltage transmission lines made power distribution away from each plant much mo- 
Figure 2: Hydro-electric Potential \& High-Voltage Transmission Lines in 1940

(A) High-Voltage Electric Grid in 1940 ( $\mathrm{km}$ of transmission lines)

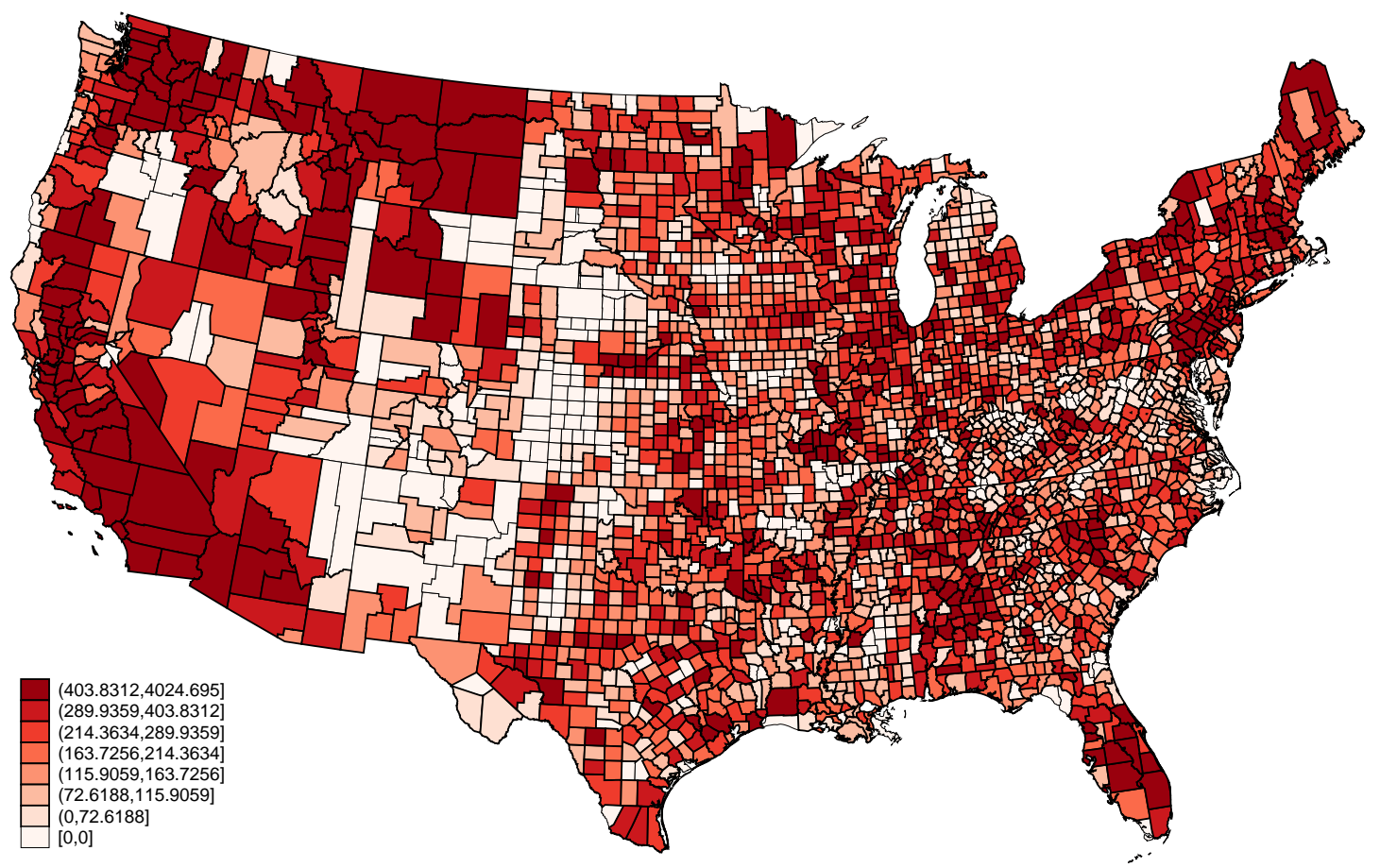

(B) Hydro-electric potential within 50 miles of County Centroid

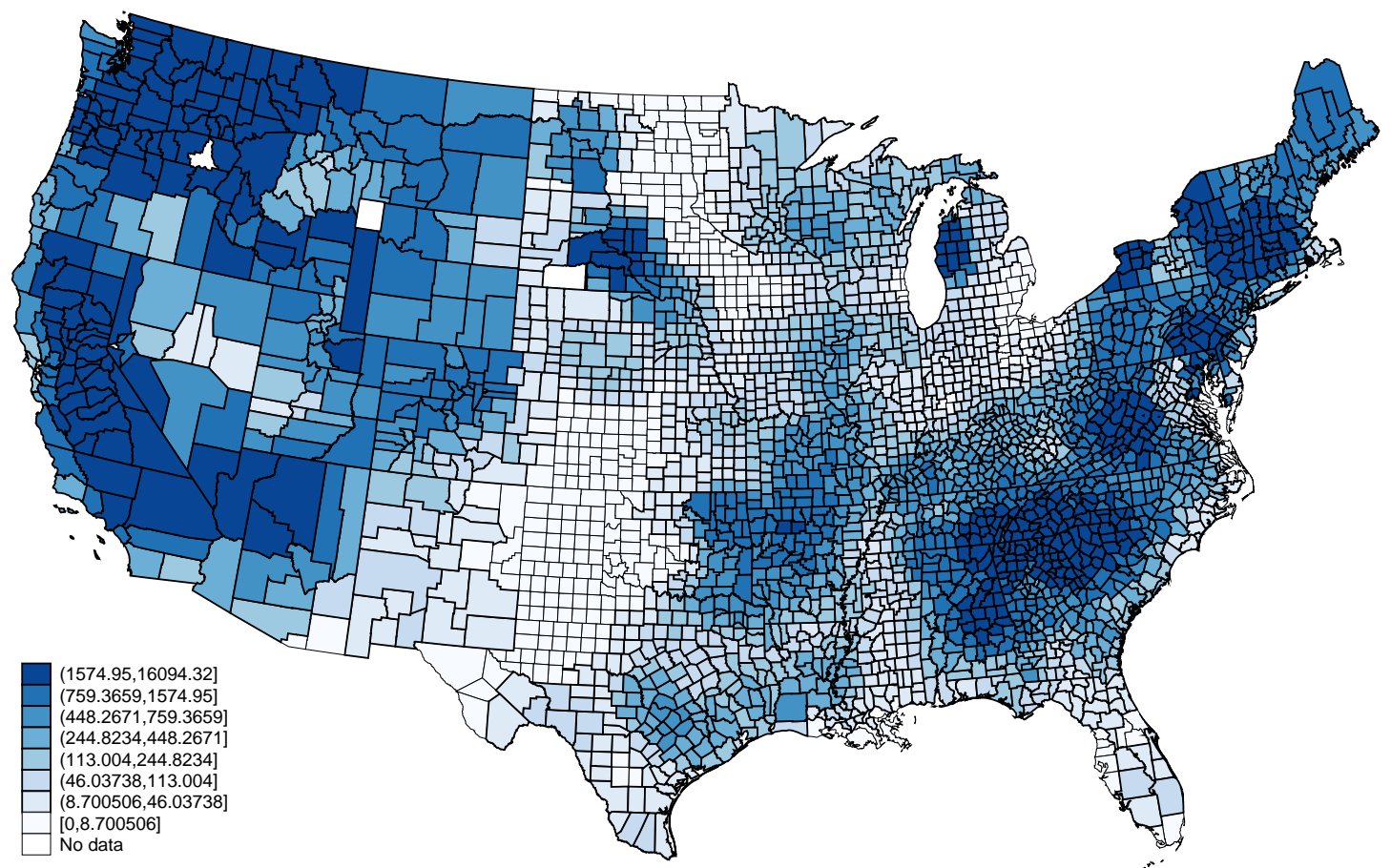

Notes: Panel A shows total kilometers of high-voltage transmission lines within the county in 1940. Panel B shows total hydro-electric potential in Mega Watts within a 50 mile radius of the county centroid. 
re feasible.

\subsection{Labor force characteristics (Full count U.S. Census of Population)}

We draw on the full count U.S. Census of Population for the years 1910-1940 as provided under a special license by IPUMS (Ruggles, Flood, Goeken, Grover, Meyer, Pacas and Sobek, 2019). The analysis below uses data for the male, non-institutionalized, working age population (16-65), sometimes restricted to those who reported a codeable occupation and industry. The Census of course gives us a range of demographic and location information, along with labor market outcomes for our subsample. Unfortunately, wage and salary income was only reported in 1940 so we cannot make specific statements about the income implications of our results because we cannot control for 1910 income.

Our main outcomes for quantifying structural changes in the labor market are the occupations and industries recorded in the Census. In particular, we draw on IPUMS's harmonized occupation and industry codes occ1950 and ind1950, which are standard across our sample period.

IPUMS assigned these harmonized codes based on the original text recorded by the Census enumerator, which is available to us (with restricted access) in digitized form as occstr and indstr. Unfortunately, as of October 2018, a non-negligible subset of individuals in the 1910, 1920, and 1930 files receive occ1950 and ind1950 code 979, which indicates that IPUMS has "not yet coded" an individual's industry and/or occupation. We develop a simple procedure in order to drastically reduce the number of 979

codes in the original IPUMS files (see Appendix A for details). In the raw IPUMS files, roughly $7 \%$ of individuals are coded as 979 in the 1910-1930 files. Our procedure reduces this number to roughly $6 \%$ for occ1950-ind1950 tuples and to less than 3\% for occupations (occ11950), since occstr tended to contain much more information than indstr.

For our main analyses we aggregate the harmonized IPUMS occupation and industry codes to the one digit level, effectively resulting in 10 occupation groups and 9 broad sectors.

\subsection{Defining Geography}

All of our analyses are at the county level. Since county boundary definitions change over the period 1910-1940 we use Hornbeck's (2010) method to hold 1910 county definitions fixed and proportionately re- 
allocate all county-level aggregates as if the data were uniformly distributed across locations within a county. For example, New York county was split into Manhattan and the Bronx in 1914, which falls between the 1910 and 1920 censuses. To keep geographic areas comparable over time, we therefore define a synthetic New York county for 1920-1940 which adds the outcomes for 1920-1940 in the Bronx and Manhattan. In other cases, when a newer county definition contains all or portions of multiple 1910 counties, the outcomes are weighted by their respective share in area of the newer county definition. The changes in county areas are calculated based on historical county definitions using standard GIS software. We note that this adjustment is applied at the county level to all three data sources described above.

\subsection{Econometric specification}

In our main analysis, we estimate the following cross sectional regression for a given Census year:

$$
y_{i}=\beta_{0}+\beta_{1} E_{i}+\beta_{2} X_{i}+\beta_{3} y_{i, 0}+\tau_{i}+\epsilon_{i}
$$

Counties are indexed by $i$, and $E_{i}$ is the number of kilometers of high-voltage power lines in county $i$ : this is by definition a cumulative measure of electrification, capturing the stock of power lines to date. We control for state fixed effects, $\tau_{i}$, and various county level characteristics, $X_{i}$, calculated on the same subsample of the population we use for our outcomes in 1910 when there were essentially no high-voltage power lines (Table 2). $X_{i}$ includes logged population density (to account for initial differences in levels of development), the fraction of white individuals, the average age (see Table 1 for summary statistics). Finally, we include as a control the outcome at period $0, y_{i, 0}$. Observations are weighted by county population in 1910 and standard errors are robust.

Running this specification with different end years $t$ allows us to trace the short to long-term impact of electrification. We focus on the long-run effects in our main estimates, choosing $t=1940$.

The most likely confound for OLS regressions is that electrification was demand driven: electrification may occur sooner in counties where electricity-intensive occupations and industries were already strong . To get around this potential confound, we use an instrument for electrification that is a plausibly exogenous supply-side shifter: hydro-electric potential in an area decreases the cost of electrification. In our instrumental variable specifications, $E_{i}$ is instrumented by hydro-electric potential within 50 kilometers of the 
Table 1: Summary Statistics in 1910

\begin{tabular}{lrrrrr} 
& Mean & Std. Dev. & $p^{25}$ & $p^{50}$ & \multicolumn{1}{c}{$p^{75}$} \\
\hline \% White & 86.26 & 20.56 & 79.64 & 97.26 & 99.58 \\
Hydro potential (50 miles) & 709.79 & 1340.98 & 45.82 & 244.92 & 759.75 \\
Avg. age & 35.05 & 1.44 & 33.97 & 34.92 & 36.01 \\
People per square mile & 24.06 & 167.07 & 3.02 & 7.39 & 11.55 \\
\% Urban Counties & 6.05 & 23.85 & 0.00 & 0.00 & 0.00 \\
\hline
\end{tabular}

Notes: The table reports unweighted averages across county aggregates.

county.

Other studies have used similar approaches to our identification strategy. Dinkelman (2011) used gradient as an instrument for the electric grid in South Africa, to analyze the effect of the rollout of the grid to more remote areas after the end of apartheid. Lipscomb, Mobarak and Barham (2013) built an engineering model of the ideal rollout of the electric grid in Brazil, assuming a counterfactual world where political factors are shut down. They use this as an instrument for the actual grid and analyze the impact on growth through various channels including agricultural productivity. This is similar to our use of hydro-electric potential as an instrument, which captures just the exogenous geographic variation in the cost of electricity. Lewis and Severnini (2017) use the distance to power plants for counties in the U.S., from 1930 to 1960, to identify exogenous variation in electricity cost. They point out that rural customers made up a small fraction of the overall customer base, reducing the threats to identification of their approach. In our study too, we focus mainly on rural areas, and farm service made up only $2.6 \%$ of nationwide electricity customers in 1932 , implying that their actions would not have driven transmission line or power plant placement (Kitchens and Fishback, 2015, 1163). Severnini (2014) also looked at areas that had similar hydro-electric potential, comparing those that eventually built dams to those that did not, to measure the agglomeration effects of expanding infrastructure.

\subsection{Descriptive statistics}

In 1910, only $6 \%$ of the counties are urban (Table 1), so our sample is overwhelmingly rural. In additional results below, we will consider the effects of electricity separately for rural and urban counties.

How did the U.S. economy change between 1910 and 1940 in terms of its occupation and industry structure? In Figure 3, panel A, we order occupations from the most common to the least common in 1910 
Table 2: National Trends in High-Voltage Power Transmission Lines: 1910-1940

\begin{tabular}{|c|c|c|c|c|c|c|}
\hline & \multicolumn{6}{|c|}{ Average km of Transmission Lines within County } \\
\hline & \multicolumn{3}{|c|}{ Average } & \multicolumn{3}{|c|}{1910 County Pop. Weighted Average } \\
\hline & All Counties & Urban & Rural & All Counties & Urban & Rural \\
\hline Level (\%) 1910 & $\begin{array}{c}2.6^{\star * *} \\
(0.3)\end{array}$ & $\begin{array}{l}5.6^{* *} \\
(2.2)\end{array}$ & $\begin{array}{c}2.4^{* * *} \\
(0.3)\end{array}$ & $\begin{array}{c}7.4^{* * *} \\
(1.6)\end{array}$ & $\begin{array}{l}7.3^{* *} \\
(3.3)\end{array}$ & $\begin{array}{c}7.4^{* * *} \\
(1.7)\end{array}$ \\
\hline$\Delta 1920$ & $\begin{array}{c}12.5^{\star * *} \\
(1.1)\end{array}$ & $\begin{array}{c}22.9^{* * *} \\
(5.5)\end{array}$ & $\begin{array}{c}11.8^{\star * \star} \\
(1.1)\end{array}$ & $\begin{array}{c}25.9^{* * *} \\
(8.1)\end{array}$ & $\begin{array}{c}20.6^{* *} \\
(8.3)\end{array}$ & $\begin{array}{l}29.5^{\star *} \\
(12.2)\end{array}$ \\
\hline$\Delta 1930$ & $\begin{array}{c}119.2^{* * *} \\
(2.7)\end{array}$ & $\begin{array}{c}200.0^{\star * *} \\
(11.9)\end{array}$ & $\begin{array}{c}114.0^{* * *} \\
(2.7)\end{array}$ & $\begin{array}{c}203.1^{* * *} \\
(20.9)\end{array}$ & $\begin{array}{c}213.7^{\star * *} \\
(32.5)\end{array}$ & $\begin{array}{c}195.8^{\star \star *} \\
(27.6)\end{array}$ \\
\hline$\Delta 1940$ & $\begin{array}{c}206.0^{\star * *} \\
(3.9)\end{array}$ & $\begin{array}{c}327.5^{* * *} \\
(18.1)\end{array}$ & $\begin{array}{c}198.0^{\star \star *} \\
(4.0)\end{array}$ & $\begin{array}{c}402.6^{* * *} \\
(58.4)\end{array}$ & $\begin{array}{c}432.5^{\star \star *} \\
(80.2)\end{array}$ & $\begin{array}{c}380.3^{\star * *} \\
(82.7)\end{array}$ \\
\hline Obs. & 11588 & 710 & 10878 & 11588 & 710 & 10878 \\
\hline
\end{tabular}

Notes: Regression of total km of transmission lines on year dummies. Columns 4-6 are weighted by county population with occupation in 1910. HAC robust standard errors are reported in parentheses below each coefficient. Significance levels are indicated by ${ }^{*} p<0.1,{ }^{* \star} p<0.05$, and ${ }^{* * *} p<0.01$.

among working age men who have an occupation. In 1910, farmer is the most common occupation with $23.5 \%$ of men working as farmers. Generally speaking, by 1940 , the most common occupations declined while the least common expanded: the most dramatic changes occurred for farmers, whose share declined by 11.3 percentage points and for operatives, whose share increased by 6.5 percentage points (Figure 3 ), panel B) ${ }^{8}$. By 1940, operatives constitute the most common occupation with $18.2 \%$ of male employment.

Employment by industry also changed between 1910 and 1940 (Figure 3), panels C and D). While agriculture employed $36.7 \%$ of the working male population in 1910, this share declined to $21.4 \%$ by 1940 . During this same time period, manufacturing jumped up from $15.8 \%$ of the working make population to $22.9 \%$. Thus, by 1940, manufacturing replaced agriculture as the most common industry of employment among men. These trends in industrial employment are closely related to the trends in occupations where operative replaced farmer as the most common occupation for an American man between 1910 and 1940. This is broadly in line with figures quoted in (Laitner, 2000, 547) from the Historical Statistics of the United States that showed that U.S. agricultural employment shrank by about half between 1900 and 1960, while manufacturing rose by a factor of almost 3 .

Electrification as measured by power transmission lines (Table 2) started after 1910. However, relative

\footnotetext{
${ }^{8}$ These changes in the shares of farmers and operatives are qualitatively similar when we include men without an occupation (Appendix Figure B.4).
} 
Figure 3: Trends in Occupational Structure 1910-1940

(A) Avg. Employment Share

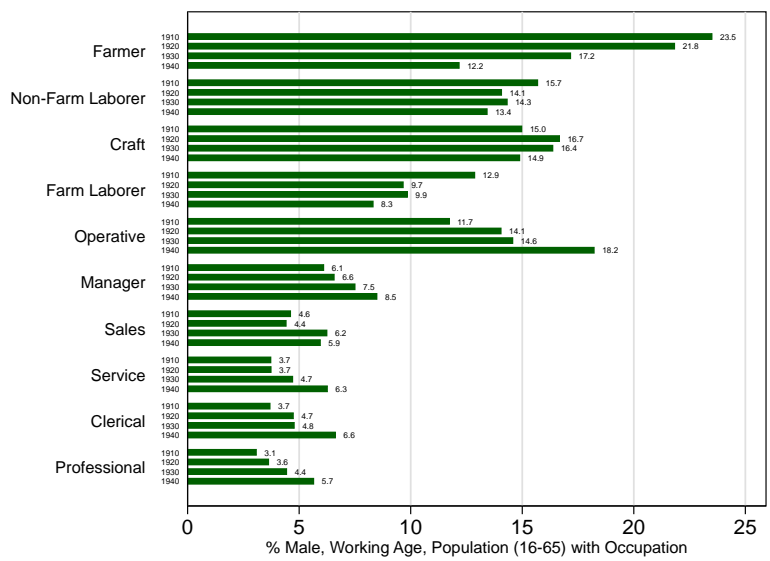

(C) Avg. Industry-Emp. Share

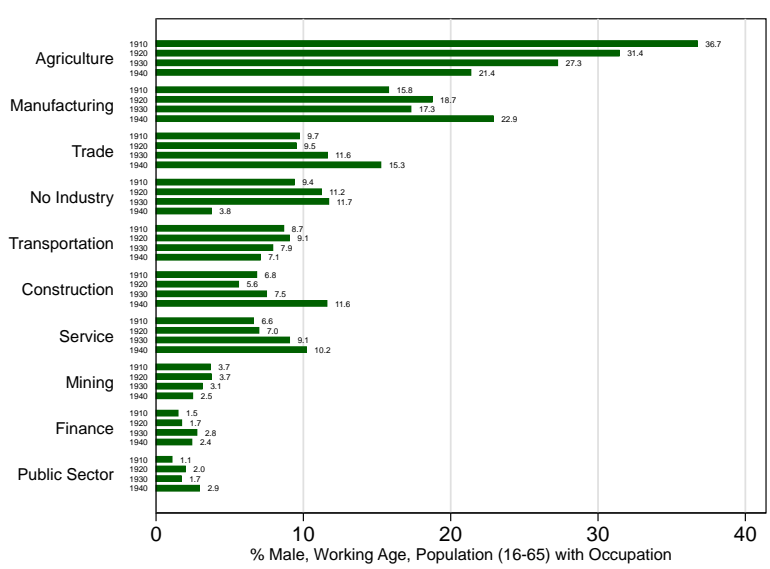

(B) Avg. Change in Emp. Share 1910-1940

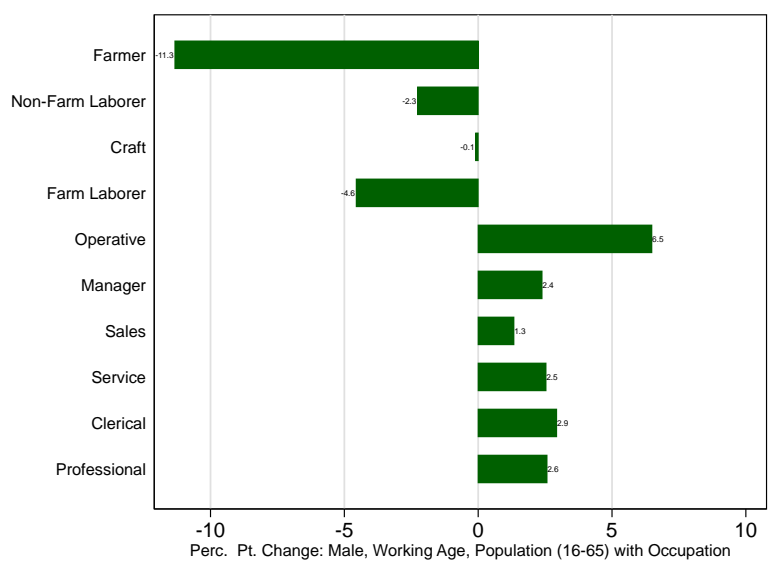

(D) Avg. Change in Industry-Emp. Share

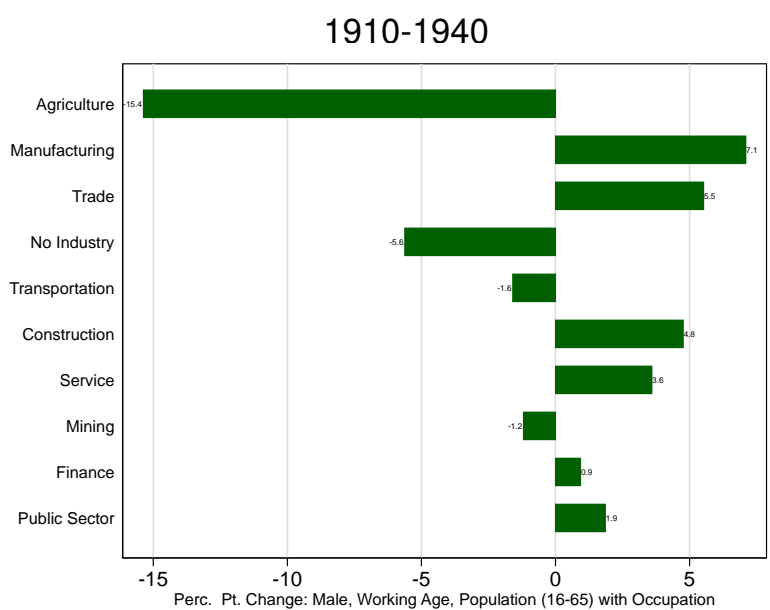

Notes: The figure shows national trends in the occupational structure during 1910-1940 in the United States. Panel A plots fractions of the male, working age population, without inmates and military who reported an occupation. Panel B displays the change from 1910-1940 as displayed in panel A. Panels B and C report analogous charts for 9 broad sectors. "No Industry" refers to individuals with an occupation but no specific/reported industry. For full regression tables of national trends in occupation and industry shares, see Appendix Tables C.9 and C.10.

to levels achieved in 1940, there is little growth in electrification between 1910 and 1920. Most of the action happens between 1920 and 1940, with the length of high-voltage power lines multiplied by two between 1920 and 1930 and again between 1930 and 1940.

Interestingly, the timing of electrification seems to coincide with the timing of changes in the share of farmers and operatives. The decline in farming between 1910 and 1920 was very limited (Figure 3), panel A). The share of farmers declines most strongly between 1920 and 1940, which is also when electrification 
Table 3: First Stage Regression

\begin{tabular}{|c|c|c|c|}
\hline & \multicolumn{3}{|c|}{$100 \mathrm{~km}$ of High Voltage Power Lines } \\
\hline & 1920 & 1930 & 1940 \\
\hline Hydro (50m Radius) & $\begin{array}{l}0.0002^{\star \star *} \\
(0.00005)\end{array}$ & $\begin{array}{c}0.0006^{\star * *} \\
(0.0001)\end{array}$ & $\begin{array}{c}0.0008^{\star * *} \\
(0.0002)\end{array}$ \\
\hline Obs. & 2895 & 2895 & 2875 \\
\hline Adj. $R^{2}$ & 0.512 & 0.442 & 0.487 \\
\hline F-Stat (Instr./not adj.) & 9.674 & 23.19 & 15.55 \\
\hline Weights & Cty. Pop. & Cty. Pop. & Cty. Pop. \\
\hline
\end{tabular}

Notes: Regression of kilometers of transmission lines on hydroelectric potential within a 50 mile radius. Regressions are weighted by male, working age individuals with an occupation in 1910 and include the same control variables as our main IV regressions, except for the initial share of a particular occupation group. Heteroskedasticity robust standard errors are reported in parentheses below each coefficient. Significance levels are indicated by ${ }^{*} p<0.1,{ }^{* *} p<0.05$, and ${ }^{\star * *} p<0.01$.

spread the most rapidly. For operatives, the strongest growth occurs between 1930 and 1940 . We will now investigate whether this coincidence of timing between electrification and structural change can be interpreted as a causal effect of electrification.

\section{Results}

In Table 3, we show a first stage regression of length of high-voltage power lines on hydro-electric potential within 50 miles of each county. This regression is not exactly the first stage for our IV because we will be including the 1910 value of the left-hand side variable as a control in each specification.

Hydro-electric potential has a positive and significant impact on electrification, and the magnitude of the effect is largest in 1940. The F-test in 1930 and 1940 is above 10, suggesting the instrument is strong enough. In our IV regressions, we will report the Kleinbergen-Paap underidentification test.

\subsection{Impact of electrification on the occupational structure of employment}

In our main results, we focus on the 1910-1940 period to capture the long-run effect of electrification on the occupational structure.

In OLS regressions (Table 4), electrification seems to thoroughly affect the structure of occupations between 1910 and 1940: it significantly decreases the share of farmers and farm laborers and non-farm 
Table 4: OLS: Effect of Electrification on Occupations (1910-1940)

\begin{tabular}{|c|c|c|c|c|c|}
\hline & \multicolumn{5}{|c|}{ Percent of Male, Working Age Population (15-65) with Occupation in 1940} \\
\hline & Farmer & Farm Lab. & Clerical & Sales & Craft \\
\hline TL in $100 \mathrm{~km}$ & $\begin{array}{c}-0.5^{\star * *} \\
(0.10)\end{array}$ & $\begin{array}{c}-0.2^{\star \star *} \\
(0.06)\end{array}$ & $\begin{array}{c}0.08^{\star \star *} \\
(0.02)\end{array}$ & $\begin{array}{c}0.09^{* * *} \\
(0.01)\end{array}$ & $\begin{array}{l}0.2^{\star \star *} \\
(0.03)\end{array}$ \\
\hline Obs. & 2875 & 2875 & 2875 & 2875 & 2875 \\
\hline \multirow[t]{2}{*}{ Adj. $R^{2}$} & 0.8 & 0.6 & 0.8 & 0.7 & 0.8 \\
\hline & Operatives & Professional & Service & Managerial & Non-Farm Lab. \\
\hline TL in $100 \mathrm{~km}$ & $\begin{array}{l}0.4^{\star * *} \\
(0.07)\end{array}$ & $\begin{array}{l}0.1^{* * *} \\
(0.02)\end{array}$ & $\begin{array}{c}0.07^{* \star *} \\
(0.01)\end{array}$ & $\begin{array}{c}0.07^{* * *} \\
(0.02)\end{array}$ & $\begin{array}{c}-0.2^{* * *} \\
(0.04)\end{array}$ \\
\hline Obs. & 2875 & 2875 & 2875 & 2875 & 2875 \\
\hline Adj. $R^{2}$ & 0.6 & 0.4 & 0.7 & 0.6 & 0.5 \\
\hline
\end{tabular}

Notes: Regression of county occupation share on kilometers of high-voltage transmission lines (TL) and additional control variables discussed in the text, weighted by county population in 1910. Heteroskedasticity robust standard errors are reported in parentheses below each coefficient. Significance levels are indicated by ${ }^{*} p<0.1,{ }^{* *} p<0.05$, and ${ }^{* * *} p<0.01$.

Table 5: IV: Effect of Electrification on Occupations (1910-1940)

\begin{tabular}{lccccc} 
& \multicolumn{5}{c}{ Percent of Male, Working Age Population (15-65) with Occupation in 1940} \\
\cline { 2 - 6 } & Farmer & Farm Lab. & Clerical & Sales & Craft \\
\hline TL in 100 km & $-0.5^{* * *}$ & -0.08 & 0.003 & 0.006 & $0.3^{* * *}$ \\
& $(0.2)$ & $(0.1)$ & $(0.07)$ & $(0.04)$ & $(0.10)$ \\
& & & & & \\
Obs. & 2875 & 2875 & 2875 & 2875 & 2875 \\
Adj. R & 0.9 & 0.8 & 0.9 & 0.9 & 0.8 \\
KP 1 $1^{\text {st }}$ St. F & 19.3 & 20.1 & 21.2 & 23.7 & 20.7 \\
KP p-value & 0.000 & 0.000 & 0.000 & 0.000 & 0.000 \\
& & & & & \\
& Operatives & Professional & Service & Managerial & Non-Farm Lab. \\
\hline TL in 100 km & $0.8^{* * *}$ & $0.1^{* * *}$ & 0.05 & -0.04 & -0.1 \\
& $(0.2)$ & $(0.05)$ & $(0.07)$ & $(0.05)$ & $(0.1)$ \\
& & & & & \\
Obs. & 2875 & 2875 & 2875 & 2875 & 2875 \\
Adj. R & 0.6 & 0.7 & 0.9 & 0.8 & 0.6 \\
KP 1 ${ }^{\text {st }}$ St. F & 15.4 & 21.7 & 20.0 & 21.0 & 15.9 \\
KP p-value & 0.000 & 0.000 & 0.000 & 0.000 & 0.000 \\
& & & & &
\end{tabular}

Notes: Regression of county occupation share on kilometers of high-voltage transmission lines (TL) and additional control variables discussed in the text, weighted by county population in 1910. High-voltage transmission lines are instrumented with hydroelectric potential within 50 miles of the county centroid. Heteroskedasticity robust standard errors are reported in parentheses below each coefficient. Significance levels are indicated by ${ }^{*} p<0.1,{ }^{* *} p<0.05$, and ${ }^{* * *} p<0.01$.

laborers, and increases the share of clerical, sales, craft, operatives, professional, service and management workers. 
We then move on to instrumental variables estimation; the p-values of the Kleibergen-Paap underidentification test imply that we can reject underidentification at the $1 \%$ level for all occupations. Once we instrument for the length of high-voltage power lines with hydro-electric potential (Table 5), there are fewer significant effects of electrification on the occupational structure. Electrification decreases the share of men employed in farming, and increases the shares employed in craft, operatives and professional occupations. In terms of magnitudes, the largest effects are on farmers and operatives: a 100 kilometers of high-voltage power lines decreases the share of farmers by 0.5 percentage points and increases the share of operatives by 0.4 percentage points. The effect of electrification on farmers is not different when using IV relative to OLS, while IV doubles the magnitude of the effect of electrification on operatives. This suggests that increases in electrification occurred in counties where the growth of operatives tended to be otherwise slower, leading to a downward bias in the OLS estimates.

\subsection{Impact of electrification on the industrial structure of employment}

We now investigate the impact of electrification on the industrial structure between 1910 and 1940 . We note that industry is missing for up to $28 \%$ of workers depending on occupation (see Appendix Table C.24), so we also incorporate the effect of electrification on the "missing industry" category.

Using OLS (Table 6), we find that electrification affected industry employment across the board, significantly reducing the share of males employed in agriculture and increasing the share employed in trade, finance, services, and the public sector, as well as increasing the share of men without a reported industry. Quantitatively, the largest effects of electrification are the decline in agriculture and the increase in manufacturing, which corresponds to the structural transformation.

We then move on to IV. The p-values of the Kleibergen-Paap underidentification tests imply that we can reject underidentification at the $1 \%$ level for all industries (Table 7).

When instrumenting electrification with hydro-electric potential (Table 7), electrification significantly decreases the share of men employed in agriculture and increases the share of men employed in manufacturing. Electrification also increases employment in construction and decreases employment in transportation. A $100 \mathrm{~km}$ increase in high-voltage power lines lowers the share of men employed in agriculture by 0.6 percentage points and increases the share of men employed in manufacturing by 0.5 percentage points. The 
Table 6: OLS: Effect of Electrification on Industries (1910-1940)

\begin{tabular}{|c|c|c|c|c|c|}
\hline & \multicolumn{5}{|c|}{ Percent of Male, Working Age Population (15-65) with Occupation in 1940} \\
\hline & 1. Ag. & 2. Mining & 3. Const. & 4. Manu. & 5. Transp. \\
\hline TL in $100 \mathrm{~km}$ & $\begin{array}{c}-0.7^{\star * *} \\
(0.1)\end{array}$ & $\begin{array}{l}0.008 \\
(0.05)\end{array}$ & $\begin{array}{c}0.04 \\
(0.04)\end{array}$ & $\begin{array}{l}0.4^{* * *} \\
(0.08)\end{array}$ & $\begin{array}{l}0.06^{\star *} \\
(0.03)\end{array}$ \\
\hline Obs. & 2875 & 2875 & 2875 & 2875 & 2875 \\
\hline \multirow[t]{2}{*}{ Adj. $R^{2}$} & 0.8 & 0.6 & 0.2 & 0.7 & 0.7 \\
\hline & 6. Trade. & 7. Fin. & 8. Serv. & 9. Pub. & 10. No Ind. \\
\hline TL in $100 \mathrm{~km}$ & $\begin{array}{l}0.2^{\star \star *} \\
(0.03)\end{array}$ & $\begin{array}{l}0.04^{\star * *} \\
(0.008)\end{array}$ & $\begin{array}{l}0.2^{\star \star \star} \\
(0.04)\end{array}$ & $\begin{array}{l}0.02^{*} \\
(0.01)\end{array}$ & $\begin{array}{c}0.05^{\star * *} \\
(0.02)\end{array}$ \\
\hline Obs. & 2875 & 2875 & 2875 & 2875 & 2875 \\
\hline Adj. $R^{2}$ & 0.7 & 0.6 & 0.4 & 0.2 & 0.3 \\
\hline
\end{tabular}

Table 7: IV: Effect of Electrification on Industries (1910-1940)

\begin{tabular}{|c|c|c|c|c|c|}
\hline & \multicolumn{5}{|c|}{ Percent of Male, Working Age Population (15-65) with Occupation in 1940} \\
\hline & 1. Ag. & 2. Mining & 3. Const. & 4. Manu. & 5. Transp. \\
\hline TL in $100 \mathrm{~km}$ & $\begin{array}{c}-0.6^{* *} \\
(0.3)\end{array}$ & $\begin{array}{c}0.02 \\
(0.07)\end{array}$ & $\begin{array}{c}0.2^{* *} \\
(0.08)\end{array}$ & $\begin{array}{l}0.5^{\star *} \\
(0.2)\end{array}$ & $\begin{array}{l}-0.2^{* *} \\
(0.08)\end{array}$ \\
\hline $\begin{array}{l}\text { Obs. } \\
\text { Adj. } R^{2} \\
\text { KP } 1^{\text {st }} \text { St. F } \\
\text { KP p-value }\end{array}$ & $\begin{array}{c}2875 \\
0.9 \\
20.0 \\
0.000\end{array}$ & $\begin{array}{c}2875 \\
0.7 \\
15.9 \\
0.000\end{array}$ & $\begin{array}{c}2875 \\
0.1 \\
19.6 \\
0.000\end{array}$ & $\begin{array}{c}2875 \\
0.8 \\
16.2 \\
0.000\end{array}$ & $\begin{array}{c}2875 \\
0.8 \\
16.4 \\
0.000\end{array}$ \\
\hline & 6. Trade. & 7. Fin. & 8. Serv. & 9. Pub. & 10. No Ind. \\
\hline TL in $100 \mathrm{~km}$ & $\begin{array}{c}0.03 \\
(0.07)\end{array}$ & $\begin{array}{l}-0.04 \\
(0.03)\end{array}$ & $\begin{array}{c}0.02 \\
(0.05)\end{array}$ & $\begin{array}{l}-0.09 \\
(0.06)\end{array}$ & $\begin{array}{c}0.2^{* *} \\
(0.08)\end{array}$ \\
\hline Obs. & 2875 & 2875 & 2875 & 2875 & 2875 \\
\hline Adj. $R^{2}$ & 0.9 & 0.8 & 0.8 & 0.4 & 0.4 \\
\hline $\mathrm{KP} 1^{s t} \mathrm{St} . \mathrm{F}$ & 21.4 & 19.7 & 19.6 & 17.7 & 18.5 \\
\hline KP p-value & 0.000 & 0.000 & 0.000 & 0.000 & 0.000 \\
\hline
\end{tabular}

Notes: Regression of county industry share on kilometers of high-voltage transmission lines (TL) and additional control variables discussed in the text, weighted by county population in 1910. High-voltage transmission lines are instrumented with hydroelectric potential within 50 miles of the county centroid. Heteroskedasticity robust standard errors are reported in parentheses below each coefficient. Significance levels are indicated by ${ }^{*} p<0.1,{ }^{* *}$ $p<0.05$, and ${ }^{* * *} p<0.01$.

results for agriculture and manufacturing are consistent with our occupational results showing that electrification decreased the share of farmers and increased the share of operatives. These results show that 
Table 8: Approximate Contribution of Electrification to Structural Transformation

\begin{tabular}{clll}
\multicolumn{2}{c}{ Occupations } & \multicolumn{2}{c}{ Sectors } \\
Farmers & Operatives & Agriculture & Manufacturing \\
\hline
\end{tabular}

A. Fraction of Male, Working Age Population (16-65) with Occupation

$\begin{array}{lcccc}\text { Initial } & 23.5 & 11.7 & 36.7 & 15.8 \\ \text { Change } & -11.3 & 6.5 & -15.4 & 7.1 \\ 1940 & 12.2 & 18.2 & 21.3 & 22.9\end{array}$

B. Transmission Lines in $\mathrm{km}$

$\begin{array}{lllll}\text { Change } & 402.6 & 402.6 & 402.6 & 402.6 \\ 1940 & 410.0 & 410.0 & 410.0 & 410.0\end{array}$

C. Regression Coefficients

\begin{tabular}{lllll}
\hline OLS 1940 & -0.5 & 0.4 & -0.7 & 0.4 \\
IV 1940 & -0.5 & 0.8 & -0.6 & 0.5
\end{tabular}

\begin{tabular}{lcccccccc}
\multicolumn{2}{l}{ D. Predicted Changes } & \% of Trend & & \% of Trend & & \% of Trend & & \% of Trend \\
\hline OLS & -2.0 & 17.8 & 1.6 & 24.8 & -2.8 & 18.3 & 1.6 & 22.7 \\
IV & -2.1 & 18.1 & 3.3 & 50.5 & -2.4 & 15.7 & 2.0 & 28.4
\end{tabular}

Notes: The table reports back of the envelope calculations on the approximate contribution of electrification to the decline in farmers and the rise of operatives. National trends in panel A are taken from Tables C.9 and C.10. National trends in electrical grid expansion in panel B are taken from Table 2. Estimates of the impact of grid expansion on occupational and industrial composition of employment are taken from Tables 4 and 5 for occupations as well as 6 and 7 for sectors.

electrification played a role in structural transformation, which we will now quantify more precisely.

\subsection{Implied effects of electrification on structural transformation}

Table 8 summarizes a back of the envelope calculation to gauge the contribution of electrification to structural transformation between 1910 and 1940. Scaling our IV estimates from Table 5 and with the average county-level increase in high-voltage transmission lines, we find that electrification explains roughly $18 \%$ of the national decline in the employment share of farmers between 1910 and 1940 and about $50 \%$ of the increase in the employment share of operatives.

An analogous calculation for industries based on Table 7 suggests that electrification accounts for $15 \%$ of the decline in the employment share of agriculture and about $28 \%$ of the increase in the employment share of manufacturing. Electrification may have a lower impact on industries than on occupations because agriculture and manufacturing are comprised of other occupations besides farmers and operatives respectively (Appendix Tables C.23 and C.25): in agriculture, the share of farmers is about two thirds in 1910, and in manufacturing, operatives constitute only 28\% of employment in 1910 (Appendix Table C.23). Fur- 
thermore, while farmers are essentially only found in agriculture, one can find operatives in other industries besides manufacturing (Appendix Tables C.24 and C.26): for example, in 1910, 37\% of operatives were in manufacturing and 29\% were in mining (Appendix Table C.24).

Overall, the picture that emerges from our results is that electrification played a causal role in moving American employment away from farming occupations and toward operatives occupations, explaining a significant share of the structural transformation in early twentieth century U.S.. Figure 1 graphically illustrates these back of the envelope calculations for the entire occupational and indstrial structure.

\subsection{Additional results and robustness tests}

The effects of electrification could be different between rural and urban counties. In Appendix Tables C.15 (OLS) and C.16 (IV), we add an interaction between a dummy for a county being urban and electrification. We find that the impact of electrification between 1910 and 1940 on farmers and operatives is driven by rural counties. Similarly, the effect of electrification on agriculture and manufacturing are driven by rural counties, though results are imprecise for agriculture (Appendix Table C.21 for OLS, and C.22 for IV). Therefore, it appears that electrification accelerated structural transformation within rural counties in the U.S. rather than changing the occupational structure in urban counties.

What are the effects of electrification during different decades? We start with changes between 1910 and 1920. During this decade, there was little increase in electrification (Table 2) and the instrument is relatively weak (Table 3) so we should not over-interpret the results. In terms of occupations, IV regressions ${ }^{9}$ show a significant increase in the share of sales and professional occupations (Appendix Table C.12). In terms of industries, IV results ${ }^{10}$ show a significant decline in mining, transportation and public services and a significant increase in construction, trade, and services (Appendix Table C.18).

Between 1910 and 1930, electrification increases considerably (Table 2). IV regressions ${ }^{11}$ show that electrification significantly increased the share of operatives in male employment (Appendix Table C.14), though the effect is smaller than for 1940, consistent with this being an earlier period. The impact on farmers in 1930 is less than half as large as the impact on farmers in 1940 and is not statistically significant. This

\footnotetext{
${ }^{9}$ See Appendix Table C.11 for corresponding OLS regressions.

${ }^{10}$ See Appendix Table C.12 for corresponding OLS regressions.

${ }^{11}$ See Appendix Table C.13 for corresponding OLS regressions.
} 
suggests that electrification had an earlier effect on operatives than on farmers.

As for the impact of electrification on the industry structure in 1930, the IV results ${ }^{12}$ show a significant positive effect on manufacturing but not yet a significant negative effect on farming (Appendix Table C.20). This is consistent with the historical evidence cited above that wages in agriculture only started to collapse in the 1930s.

Overall, electrification spread most vigorously in the 1920s and 1930s, and we correspondingly observe a causal significant and positive effect on the share of operatives in male employment in both 1930 and 1940, and a causal significant and negative impact on the share of farmers in 1940. In parallel, we see already a significant positive effect of electrification on manufacturing in 1930 and 1940, and a significant negative effect on farming by 1940. This suggests that electrification played a causal role in structural transformation by stimulating job creation for operatives and the growth of the manufacturing sector, and in a second time facilitated the decline in farmers and the shrinking of the agriculture industry.

\section{Conclusion}

In this paper, we leverage a new combination of U.S. Census data and electricity data on hydro-electric potential and high-voltage power lines to examine the impact of electrification on the employment structure in the early twentieth century U.S.. We instrument the length of high-voltage power lines in a county with hydro-electric potential with 50 miles of that county. We find that the average increase in the length of high-voltage power lines between 1910 and 1940 increased the share of operatives in male employment in a county by 3.3 percentage points and decreased the share of farmers by 2.1 percentage points. Electrification can explain $50.5 \%$ of the total increase in the share of operatives in male employment, and $18.1 \%$ of the total decrease in the share of farmers. At the industry level, electrification can explain $15.7 \%$ of the decline in the share of male agricultural employment and $28.4 \%$ of the increase in the share of manufacturing employment.

We find that much of the increase in operatives over this period is in rural areas rather than urban areas, suggesting that structural transformation is not just a movement between rural and urban areas but affects the structure of employment within rural areas.

The effects of electrification take a very long time to unfold, illustrating the long time scales involved

\footnotetext{
${ }^{12}$ See Appendix Table C.19 for corresponding OLS regressions.
} 
when trying to understand the impact of a general purpose technology on the labor market. First, even though electricity was developed commercially in the late 19th century, most residents and commercial activities in the U.S. did not have electricity by 1910, and only large urban areas were electrified. The development of higher-voltage power lines was very slow until 1920, and only accelerated significantly between 1920 and 1940. We show that this acceleration of electrification affected the structure of employment, especially favoring the growth of operative jobs and negatively affecting farmer jobs. The long timescale for the impact of electrification on the labor market suggests that we may see a similarly protracted development of the full impacts of ICT—-the latest general purpose technology—on the labor market.

\section{References}

Alexopoulos M, Cohen J. 2016. The medium is the measure: Technical change and employment, 1909-1949. Review of economics and statistics 98: $792-810$.

Alston LJ, Hatton TJ. 1991. The earnings gap between agricultural and manufacturing laborers, 1925-1941. The Journal of Economic History 51: 83-99.

Burlig F, Preonas L. 2016. Out of the darkness and into the light? development effects of rural electrification .

Bustos P, Caprettini B, Ponticelli J. 2016. Agricultural productivity and structural transformation: Evidence from brazil. American Economic Review 106: 1320-65.

URL http: / /www.aeaweb.org/articles?id=10.1257/aer.20131061

Conner AM, Francfort JE. 1998. Us hydropower resource assessment. Technical report, Lockheed Martin Idaho Technologies Co., Idaho National Engineering and Environmental Laboratory.

Cravino J, Levchenko AA, Rojas M. 2019. Population aging and structural transformation. Working Paper 26327, National Bureau of Economic Research.

URL http: //www.nber.org/papers/w26327

David PA, Wright G. 1999. General purpose technologies and surges in productivity: Historical reflections on the future of the ict revolution. .

Dinkelman T. 2011. The effects of rural electrification on employment: New evidence from south africa. American Economic Review 101: 30783108

Fried S, Lagakos D. 2017. Rural electrification, migration and structural transformation: Evidence from ethiopia. Unpublished manuscript, University of San Diego

Goldin C, Katz LF. 1998. The Origins of Technology-Skill Complementarity. The Quarterly Journal of Economics 113: 693-732. ISSN 0033-5533. URL https://doi.org/10.1162/003355398555720

Gollin D, Jedwab R, Vollrath D, et al. 2013. Urbanization with and without structural transformation . 
Gordon RJ. 2017. The rise and fall of American growth: The US standard of living since the civil war, volume 70. Princeton University Press.

Gray R. 2013. Taking technology to task: The skill content of technological change in early twentieth century united states. Explorations in Economic History 50: 351 - 367. ISSN 0014-4983.

URL http://www.sciencedirect.com/science/article/pii/s0014498313000144

Gray R, Kitchens C. 2018. Energy in American Economic History. In Oxford Handbook of American Economic History, volume 2. Oxford, 55-73.

Herrendorf B, Rogerson R, Valentinyi A. 2013. Two perspectives on preferences and structural transformation. American Economic Review 103: 2752-89.

Herrendorf B, Rogerson R, Valentinyi Á. 2014. Growth and Structural Transformation. In Handbook of Economic Growth, volume 2 of Handbook of Economic Growth, chapter 6. Elsevier, 855-941.

URL https://ideas.repec.org/h/eee/grochp/2-855.html

Hornbeck R. 2010. Barbed Wire: Property Rights and Agricultural Development*. The Quarterly Journal of Economics 125: 767-810. ISSN 0033-5533.

URL https://doi.org/10.1162/qjec.2010.125.2.767

Katz LF, Margo RA. 2014. Technical Change and the Relative Demand for Skilled Labor: The United States in Historical Perspective. University of Chicago Press, 15-57.

URL http: //www.nber.org/chapters/c12888

Kitchens C. 2014. The role of publicly provided electricity in economic development: The experience of the tennessee valley authority, $1929-1955$. The Journal of Economic History 74: 389-419.

Kitchens C, Fishback P. 2015. Flip the switch: the impact of the rural electrification administration 1935-1940. The Journal of Economic History 75: $1161-1195$.

Kline P, Moretti E. 2013. Local economic development, agglomeration economies, and the big push: 100 years of evidence from the tennessee valley authority. The Quarterly Journal of Economics 129: 275-331.

Kline RR. 2000. Consumers in the country: Technology and social change in rural America. Jhu Press.

Kuznets S. 1966. Modern economic growth, new heaven, ct.

Laitner J. 2000. Structural change and economic growth. The Review of Economic Studies 67: 545-561.

Lewis J, Severnini E. 2017. Short-and long-run impacts of rural electrification: evidence from the historical rollout of the us power grid .

Lipscomb M, Mobarak AM, Barham T. 2013. Development effects of electrification: Evidence from the topographic placement of hydropower plants in brazil. American Economic Journal: Applied Economics 5: 200-231.

Rud JP. 2012. Electricity provision and industrial development: Evidence from india. Journal of development Economics 97: $352-367$.

Ruggles S, Flood S, Goeken R, Grover J, Meyer E, Pacas J, Sobek M. 2019. IPUMS USA: Version 9.0 [dataset]. Minneapolis, MN: IPUMS.

URL https://doi.org/10.18128/D010.V9.0

Severnini E. 2014. The power of hydroelectric dams: Agglomeration spillovers .

World Bank. 2005. Infrastructure and the World Bank: A Progress Report. Infrastructure Vice Presidency. 


\section{Appendix A. Adjustment of 979 Occupation/Industry Codes}

We develop a simple procedure in order to drastically reduce the number of 979 codes in the original IPUMS files. To do so, we exploit the fact that IPUMS has coded different Census files sequentially, starting with 1940 and working backwards until 1910. It turns out that there are many instances in which identical entries for occstr and/or indstr appear in several Census waves, yet are assigned 979 in one Census and an actual occupation and/or industries in others. We therefore apply the following two step procedure. First, from all four Census waves during 1910-1940, we gather all unique occstr-indstr tuples that map into non-979, non-missing occ1950-ind1950 tuples. If a unique occstr-indstr tuple maps into several different occ1950-ind1950 tuples, we keep the most frequent mapping. In each Census file, we then replace any occstr-indstr tuples that are assigned 979 with the non-979, non-missing value found in the comprehensive list of the most frequent mapping from all four Census waves.

While there is some benefit to looking at occstr-indstr tuples, we repeat this procedure analogously for any remaining 979 values but using occstr by itself. We do not repeat this procedure for indstr by itself, as "industries" are in many cases coded simply as the name of an employer, or a particular location, so it is often not possible to assign an industry based on indstr in isolation. 


\section{Appendix B. Additional Figures}

Figure B.4: Trends in Occupational Structure 1910-1940: No Reported Occupation

\section{(A) Reported Occupations}

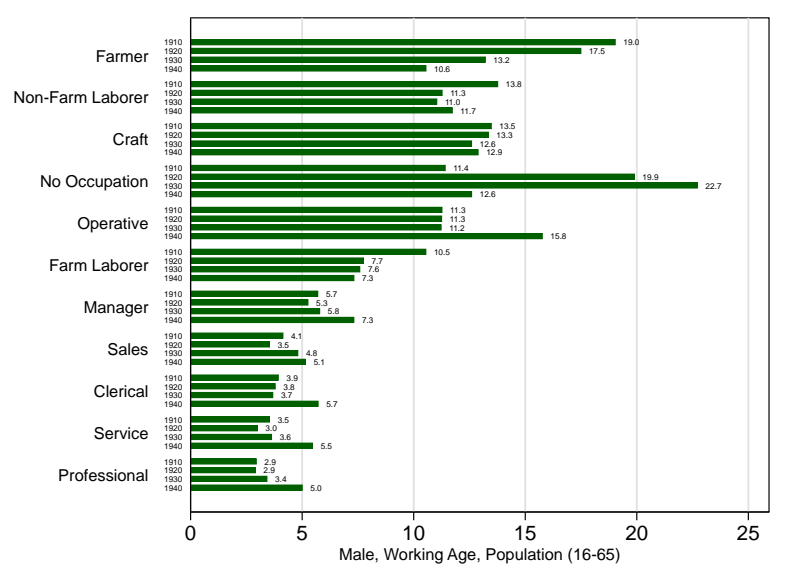

(B) No Reported Occupation

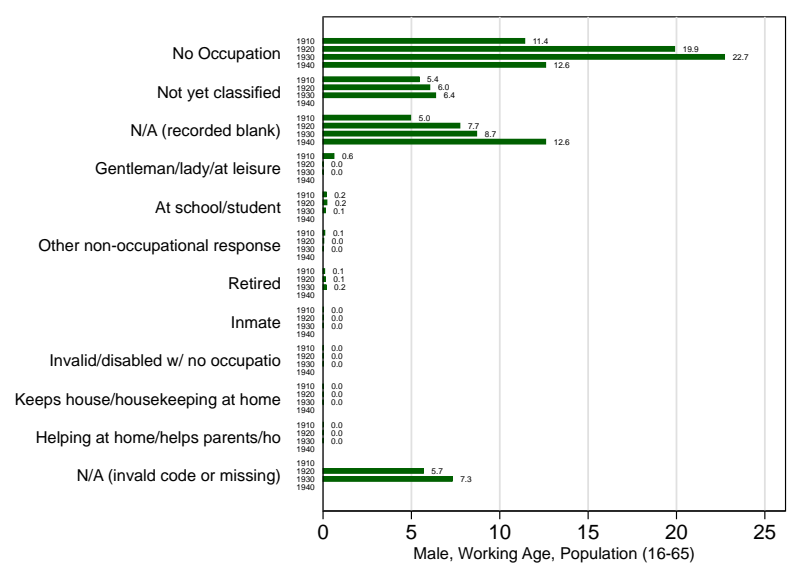

Notes: The figure shows national trends in the occupational structure during 1910-1940 in the United States. Panel A plots fractions of the male working age population, without inmates and military. Panel B decomposes the fractions of those without a reported occupation (first group of bars labeled "No Occupation") into it's sub-components based on IPUMS OCC1950 codes. 


\section{Appendix C. Additional Tables}

\section{Appendix C.1. Unconditional, National Trends}

Table C.9: National Trends in Occupation Shares 1910-1940 (County Averages)

\begin{tabular}{|c|c|c|c|c|c|}
\hline & \multicolumn{5}{|c|}{ Percent of Male, Working Age Population (15-65) with Occupation } \\
\hline & Farmer & Farm Lab. & Clerical & Sales & Craft \\
\hline Level (\%) 1910 & $23.5^{\star * *}$ & $12.9^{* * *}$ & $3.7^{* * *}$ & $4.6^{* \star *}$ & $15.0^{* * *}$ \\
\hline$\Delta 1920$ & $\begin{array}{l}-1.7 \\
(1.8)\end{array}$ & $\begin{array}{c}-3.2^{\star \star *} \\
(0.8)\end{array}$ & $\begin{array}{l}1.0^{\star *} \\
(0.4)\end{array}$ & $\begin{array}{l}-0.2 \\
(0.3)\end{array}$ & $1.7^{\star \star}$ \\
\hline$\Delta 1930$ & $\begin{array}{c}-6.3^{\star \star *} \\
(1.7)\end{array}$ & $\begin{array}{c}-3.0^{* * *} \\
(0.9)\end{array}$ & $\begin{array}{l}1.1^{* \star \star} \\
(0.4)\end{array}$ & $\begin{array}{l}1.6^{\star \star \star} \\
(0.4)\end{array}$ & $\begin{array}{l}1.4^{*} \\
(0.7)\end{array}$ \\
\hline$\Delta 1940$ & $\begin{array}{c}-11.3^{\star * \star} \\
(1.5)\end{array}$ & $\begin{array}{c}-4.6^{* * *} \\
(0.8)\end{array}$ & $\begin{array}{c}2.9^{* * *} \\
(0.4)\end{array}$ & $\begin{array}{l}1.3^{* * *} \\
(0.3)\end{array}$ & $\begin{array}{l}-0.09 \\
(0.6)\end{array}$ \\
\hline Obs. & 11763 & 11763 & 11763 & 11763 & 11763 \\
\hline & Operatives & Professional & Service & Manager & Non-Farm Lab. \\
\hline Level (\%) 1910 & $\begin{array}{c}11.7^{\star \star \star} \\
(0.5)\end{array}$ & $\begin{array}{l}3.1^{* * *} \\
(0.1)\end{array}$ & $\begin{array}{c}3.7^{* * *} \\
(0.3)\end{array}$ & $\begin{array}{c}6.1^{* * *} \\
(0.2)\end{array}$ & $\begin{array}{c}15.7^{\star \star \star} \\
(0.4)\end{array}$ \\
\hline$\Delta 1920$ & $\begin{array}{c}2.3^{\star * \star} \\
(0.7)\end{array}$ & $\begin{array}{c}0.5^{* * *} \\
(0.2)\end{array}$ & $\begin{array}{l}0.01 \\
(0.4)\end{array}$ & $\begin{array}{l}0.5^{*} \\
(0.3)\end{array}$ & $\begin{array}{c}-1.6^{* * *} \\
(0.5)\end{array}$ \\
\hline$\Delta 1930$ & $\begin{array}{c}2.8^{\star * *} \\
(0.7)\end{array}$ & $\begin{array}{l}1.4^{* * *} \\
(0.2)\end{array}$ & $\begin{array}{l}1.0^{\star *} \\
(0.4)\end{array}$ & $\begin{array}{l}1.4^{* * *} \\
(0.2)\end{array}$ & $\begin{array}{c}-1.4^{\star \star *} \\
(0.5)\end{array}$ \\
\hline$\Delta 1940$ & $\begin{array}{c}6.5^{\star * *} \\
(0.6)\end{array}$ & $\begin{array}{c}2.6^{* * *} \\
(0.2)\end{array}$ & $\begin{array}{c}2.5^{\star * *} \\
(0.4)\end{array}$ & $\begin{array}{c}2.4^{* * *} \\
(0.2)\end{array}$ & $\begin{array}{c}-2.3^{\star \star *} \\
(0.5)\end{array}$ \\
\hline Obs. & 11763 & 11763 & 11763 & 11763 & 11763 \\
\hline
\end{tabular}


Table C.10: National Trends in Industry Shares 1910-1940 (County Averages)

\begin{tabular}{|c|c|c|c|c|c|}
\hline & \multicolumn{5}{|c|}{ Percent of Male, Working Age Population (15-65) with Occupat } \\
\hline & 1. Ag. & 2. Mining & 3. Const. & 4. Manu. & 5. Transp. \\
\hline Constant(1910) & $\begin{array}{c}36.7^{\star \star \star} \\
(1.9)\end{array}$ & $\begin{array}{l}3.7^{\star \star \star} \\
(0.4)\end{array}$ & $\begin{array}{l}6.8^{\star * \star} \\
(0.2)\end{array}$ & $\begin{array}{c}15.8^{* \star \star} \\
(0.7)\end{array}$ & $\begin{array}{c}8.7^{\star * *} \\
(0.3)\end{array}$ \\
\hline$\Delta 1920$ & $\begin{array}{c}-5.3^{* *} \\
(2.6)\end{array}$ & $\begin{array}{l}0.06 \\
(0.6)\end{array}$ & $\begin{array}{c}-1.2^{\star \star \star} \\
(0.3)\end{array}$ & $\begin{array}{c}3.0^{* * *} \\
(1.0)\end{array}$ & $\begin{array}{c}0.4 \\
(0.4)\end{array}$ \\
\hline$\Delta 1930$ & $\begin{array}{c}-9.5^{* * *} \\
(2.6)\end{array}$ & $\begin{array}{l}-0.6 \\
(0.5)\end{array}$ & $\begin{array}{l}0.7^{\star \star} \\
(0.3)\end{array}$ & $\begin{array}{c}1.5 \\
(1.0)\end{array}$ & $\begin{array}{l}-0.7^{* *} \\
(0.3)\end{array}$ \\
\hline$\Delta 1940$ & $\begin{array}{c}-15.4^{\star \star *} \\
(2.3)\end{array}$ & $\begin{array}{c}-1.2^{\star *} \\
(0.5)\end{array}$ & $\begin{array}{l}4.8^{\star * *} \\
(0.3)\end{array}$ & $\begin{array}{c}7.1^{* \star *} \\
(1.1)\end{array}$ & $\begin{array}{c}-1.6^{* * *} \\
(0.3)\end{array}$ \\
\hline Obs. & 11763 & 11763 & 11763 & 11763 & 11763 \\
\hline & 6. Trade. & 7. Fin. & 8. Serv. & 9. Pub. & Total \\
\hline Constant(1910) & $\begin{array}{l}9.7^{* * *} \\
(0.6)\end{array}$ & $\begin{array}{l}1.5^{\star * *} \\
(0.1)\end{array}$ & $\begin{array}{l}6.6^{* * *} \\
(0.3)\end{array}$ & $\begin{array}{l}1.1^{* * *} \\
(0.05)\end{array}$ & $\begin{array}{l}9.4^{\star * *} \\
(0.2)\end{array}$ \\
\hline$\Delta 1920$ & $\begin{array}{l}-0.2 \\
(0.7)\end{array}$ & $\begin{array}{c}0.2 \\
(0.2)\end{array}$ & $\begin{array}{c}0.4 \\
(0.4)\end{array}$ & $\begin{array}{c}0.9^{\star \star \star} \\
(0.1)\end{array}$ & $\begin{array}{c}1.9^{\star * *} \\
(0.4)\end{array}$ \\
\hline$\Delta 1930$ & $\begin{array}{l}1.9^{\star \star *} \\
(0.7)\end{array}$ & $\begin{array}{l}1.3^{* * *} \\
(0.2)\end{array}$ & $\begin{array}{c}2.4^{* * *} \\
(0.4)\end{array}$ & $\begin{array}{l}0.6^{\star * *} \\
(0.08)\end{array}$ & $\begin{array}{c}2.3^{\star * *} \\
(0.4)\end{array}$ \\
\hline$\Delta 1940$ & $\begin{array}{c}5.5^{\star * *} \\
(0.7)\end{array}$ & $\begin{array}{l}0.9^{\star * *} \\
(0.2)\end{array}$ & $\begin{array}{l}3.6^{\star * *} \\
(0.4)\end{array}$ & $\begin{array}{l}1.9^{\star * *} \\
(0.1)\end{array}$ & $\begin{array}{c}-5.6^{* \star *} \\
(0.3)\end{array}$ \\
\hline Obs. & 11763 & 11763 & 11763 & 11763 & 11763 \\
\hline
\end{tabular}




\title{
Appendix C.2. Main Regressions Tables
}

\author{
Appendix C.2.1. Occupations
}

Table C.11: OLS: Effect of Electrification on Occupations (1910-1920)

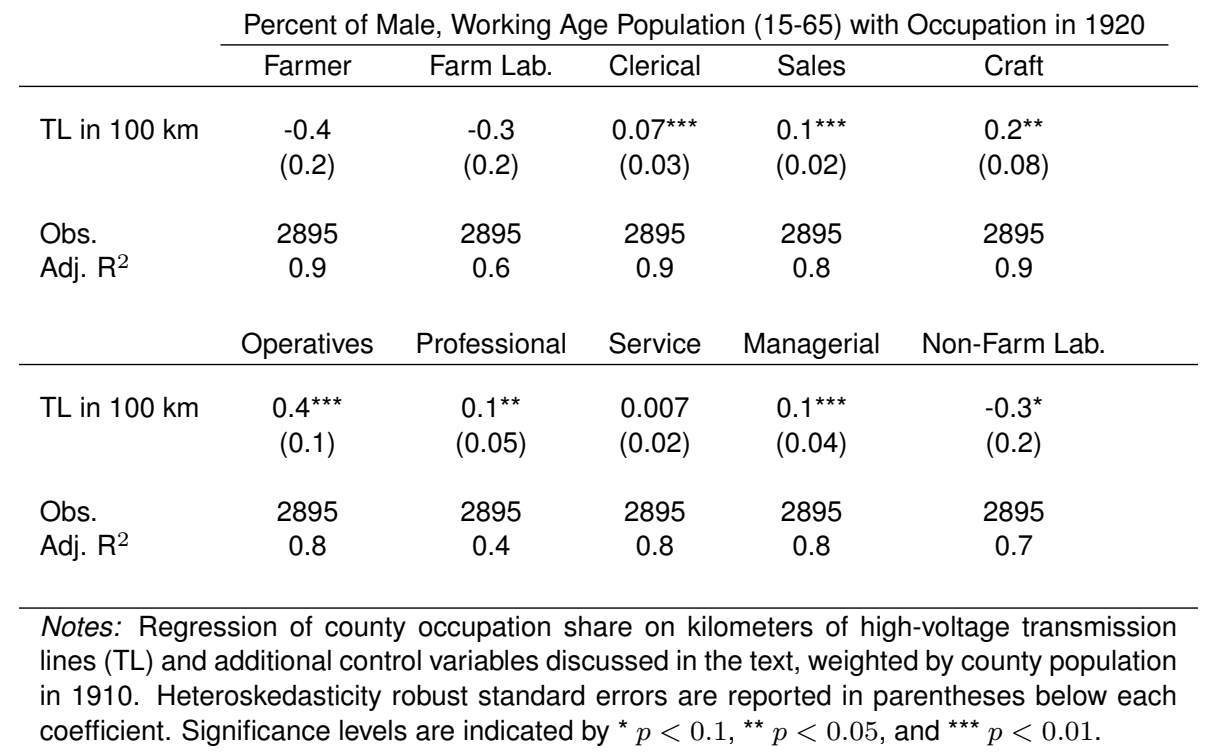


Table C.12: IV: Effect of Electrification on Occupations (1910-1920)

\begin{tabular}{|c|c|c|c|c|c|}
\hline & \multicolumn{5}{|c|}{ Percent of Male, Working Age Population (15-65) with Occupation in 1920} \\
\hline & Farmer & Farm Lab. & Clerical & Sales & Craft \\
\hline TL in $100 \mathrm{~km}$ & $\begin{array}{c}0.4 \\
(0.6)\end{array}$ & $\begin{array}{c}-0.06 \\
(0.5)\end{array}$ & $\begin{array}{l}-0.2 \\
(0.2)\end{array}$ & $\begin{array}{l}0.2^{*} \\
(0.1)\end{array}$ & $\begin{array}{c}0.6 \\
(0.6)\end{array}$ \\
\hline Obs. & 2895 & 2895 & 2895 & 2895 & 2895 \\
\hline Adj. $R^{2}$ & 0.9 & 0.9 & 1.0 & 0.9 & 0.9 \\
\hline KP $1^{\text {st }}$ St. F & 10.3 & 10.7 & 9.8 & 10.8 & 10.5 \\
\hline \multirow[t]{2}{*}{$\mathrm{KP} p$-value } & 0.002 & 0.002 & 0.003 & 0.002 & 0.002 \\
\hline & Operatives & Professional & Service & Managerial & Non-Farm Lab. \\
\hline TL in $100 \mathrm{~km}$ & $\begin{array}{c}0.3 \\
(0.5)\end{array}$ & $\begin{array}{l}0.2^{* *} \\
(0.1)\end{array}$ & $\begin{array}{c}0.2 \\
(0.2)\end{array}$ & $\begin{array}{r}-0.06 \\
(0.1)\end{array}$ & $\begin{array}{l}-0.3 \\
(0.6)\end{array}$ \\
\hline Obs. & 2895 & 2895 & 2895 & 2895 & 2895 \\
\hline Adj. $R^{2}$ & 0.9 & 0.9 & 1.0 & 0.9 & 0.8 \\
\hline $\mathrm{KP} 1^{\text {st }}$ St. F & 9.6 & 10.4 & 10.7 & 10.9 & 9.7 \\
\hline KP p-value & 0.003 & 0.002 & 0.002 & 0.002 & 0.003 \\
\hline \multicolumn{6}{|c|}{$\begin{array}{l}\text { Notes: Regression of county occupation share on kilometers of high-voltage transmission } \\
\text { lines (TL) and additional control variables discussed in the text, weighted by county population } \\
\text { in } 1910 \text {. High-voltage transmission lines are instrumented with hydro-electric potential within } \\
50 \text { miles of the county centroid. Heteroskedasticity robust standard errors are reported in } \\
\text { parentheses below each coefficient. Significance levels are indicated by }{ }^{*} p<0.1,{ }^{* *} p<0.05 \text {, } \\
\text { and }{ }^{* * *} p<0.01 \text {. }\end{array}$} \\
\hline
\end{tabular}

Table C.13: OLS: Effect of Electrification on Occupations (1910-1930)

\begin{tabular}{|c|c|c|c|c|c|}
\hline & \multicolumn{5}{|c|}{ Percent of Male, Working Age Population (15-65) with Occupation in 1930} \\
\hline & Farmer & Farm Lab. & Clerical & Sales & Craft \\
\hline TL in $100 \mathrm{~km}$ & $\begin{array}{c}-0.7^{\star \star *} \\
(0.1)\end{array}$ & $\begin{array}{l}-0.3^{\star \star \star} \\
(0.07)\end{array}$ & $\begin{array}{c}0.06^{\star \star \star} \\
(0.01)\end{array}$ & $\begin{array}{l}0.1^{* * *} \\
(0.01)\end{array}$ & $\begin{array}{l}0.2^{* \star \star} \\
(0.04)\end{array}$ \\
\hline $\begin{array}{l}\text { Obs. } \\
\text { Adj. } R^{2}\end{array}$ & $\begin{array}{c}2895 \\
0.8\end{array}$ & $\begin{array}{c}2895 \\
0.6\end{array}$ & $\begin{array}{c}2895 \\
0.9\end{array}$ & $\begin{array}{c}2895 \\
0.8\end{array}$ & $\begin{array}{c}2895 \\
0.8\end{array}$ \\
\hline & Operatives & Professional & Service & Managerial & Non-Farm Lab. \\
\hline $\mathrm{TL}$ in $100 \mathrm{~km}$ & $\begin{array}{l}0.5^{\star * *} \\
(0.08)\end{array}$ & $\begin{array}{c}0.10^{\star \star *} \\
(0.02)\end{array}$ & $\begin{array}{c}0.06^{\star \star \star} \\
(0.01)\end{array}$ & $\begin{array}{l}0.1^{* * *} \\
(0.02)\end{array}$ & $\begin{array}{c}-0.2^{* * *} \\
(0.07)\end{array}$ \\
\hline $\begin{array}{l}\text { Obs. } \\
\text { Adj. } R^{2}\end{array}$ & $\begin{array}{c}2895 \\
0.7\end{array}$ & $\begin{array}{c}2895 \\
0.4\end{array}$ & $\begin{array}{c}2895 \\
0.8\end{array}$ & $\begin{array}{c}2895 \\
0.7\end{array}$ & $\begin{array}{c}2895 \\
0.7\end{array}$ \\
\hline
\end{tabular}

Notes: Regression of county occupation share on kilometers of high-voltage transmission lines (TL) and additional control variables discussed in the text, weighted by county population in 1910. Heteroskedasticity robust standard errors are reported in parentheses below each coefficient. Significance levels are indicated by ${ }^{*} p<0.1$, $^{\star *} p<0.05$, and ${ }^{* \star *} p<0.01$. 
Table C.14: IV: Effect of Electrification on Occupations (1910-1930)

\begin{tabular}{lccccc} 
& \multicolumn{5}{c}{ Percent of Male, Working Age Population (15-65) with Occupation in 1930} \\
\cline { 2 - 6 } & Farmer & Farm Lab. & Clerical & Sales & Craft \\
\hline TL in 100 km & -0.2 & -0.009 & -0.07 & 0.02 & $0.4^{* * *}$ \\
& $(0.2)$ & $(0.2)$ & $(0.07)$ & $(0.05)$ & $(0.1)$ \\
& & & & & \\
Obs. & 2895 & 2895 & 2895 & 2895 & 2895 \\
Adj. R & 0.9 & 0.8 & 0.9 & 0.9 & 0.9 \\
KP 1 ${ }^{\text {st }}$ St. F & 27.2 & 27.6 & 26.2 & 29.7 & 28.7 \\
KP p-value & 0.000 & 0.000 & 0.000 & 0.000 & 0.000 \\
& & & & & \\
& Operatives & Professional & Service & Managerial & Non-Farm Lab. \\
\hline TL in 100 km & $0.5^{* * *}$ & 0.06 & 0.07 & 0.005 & $-0.3^{*}$ \\
& $(0.1)$ & $(0.04)$ & $(0.06)$ & $(0.05)$ & $(0.2)$ \\
Obs. & & & & & \\
Adj. R ${ }^{2}$ & 2895 & 2895 & 2895 & 2895 & 2895 \\
KP 1 ${ }^{\text {st }}$ St. F & 0.8 & 0.8 & 0.9 & 0.9 & 0.7 \\
KP p-value & 22.7 & 26.8 & 26.3 & 27.4 & 24.3 \\
& 0.000 & 0.000 & 0.000 & 0.000 & 0.000 \\
\hline Notes: Regression & & & & & \\
\hline
\end{tabular}

Notes: Regression of county occupation share on kilometers of high-voltage transmission lines $(T L)$ and additional control variables discussed in the text, weighted by county population in 1910. High-voltage transmission lines are instrumented with hydro-electric potential within 50 miles of the county centroid.Heteroskedasticity robust standard errors are reported in parentheses below each coefficient. Significance levels are indicated by ${ }^{*} p<0.1$, ${ }^{* *} p<0.05$, and ${ }^{* * *} p<0.01$.

Table C.15: OLS/Urban/Rural: Effect of Electrification on Occupations (1910-1940)

\begin{tabular}{|c|c|c|c|c|c|}
\hline & \multicolumn{5}{|c|}{ Percent of Male, Working Age Population (15-65) with Occupation in 1940} \\
\hline & Farmer & Farm Lab. & Clerical & Sales & Craft \\
\hline \multirow[t]{2}{*}{ TL in $100 \mathrm{~km}$} & $-0.6^{* * *}$ & $-0.2^{* * *}$ & $0.07^{* * *}$ & $0.08^{* * *}$ & $0.2^{\star \star \star}$ \\
\hline & $(0.1)$ & $(0.06)$ & $(0.02)$ & $(0.01)$ & $(0.04)$ \\
\hline \multirow[t]{2}{*}{ TL in $100 \mathrm{~km} \times$ Urban } & $0.4^{* *}$ & $0.2^{*}$ & 0.07 & 0.05 & -0.1 \\
\hline & $(0.2)$ & $(0.1)$ & $(0.04)$ & $(0.05)$ & $(0.08)$ \\
\hline \multirow{3}{*}{$\begin{array}{l}\text { Obs. } \\
\text { Adj. } R^{2}\end{array}$} & 2875 & 2875 & 2875 & 2875 & 2875 \\
\hline & 0.8 & 0.6 & 0.8 & 0.7 & 0.8 \\
\hline & Operatives & Professional & Service & Managerial & Non-Farm Lab. \\
\hline \multirow[t]{2}{*}{ TL in $100 \mathrm{~km}$} & $0.4^{\star * *}$ & $0.1^{* * *}$ & $0.08^{* * *}$ & $0.06^{\star * *}$ & $-0.2^{\star * *}$ \\
\hline & $(0.08)$ & $(0.02)$ & $(0.01)$ & $(0.02)$ & $(0.05)$ \\
\hline \multirow[t]{2}{*}{ TL in $100 \mathrm{~km} \times$ Urban } & $-0.4^{\star \star \star}$ & -0.09 & $-0.10^{*}$ & 0.08 & 0.02 \\
\hline & $(0.1)$ & $(0.06)$ & $(0.05)$ & $(0.05)$ & $(0.1)$ \\
\hline Obs. & 2875 & 2875 & 2875 & 2875 & 2875 \\
\hline Adj. $R^{2}$ & 0.6 & 0.4 & 0.7 & 0.6 & 0.5 \\
\hline
\end{tabular}

Notes: Regression of county occupation share on kilometers of high-voltage transmission lines (TL) and additional control variables discussed in the text, weighted by county population in 1910 . Heteroskedasticity robust standard errors are reported in parentheses below each coefficient. Significance levels are indicated by ${ }^{*} p<0.1,{ }^{* *} p<0.05$, and ${ }^{* * *} p<0.01$. 
Table C.16: IV/Urban/Rural: Effect of Electrification on Occupations (1910-1940)

\begin{tabular}{|c|c|c|c|c|c|}
\hline & \multicolumn{5}{|c|}{ Percent of Male, Working Age Population (15-65) with Occupation in 1940} \\
\hline & Farmer & Farm Lab. & Clerical & Sales & Craft \\
\hline \multirow[t]{2}{*}{ TL in $100 \mathrm{~km}$} & $-1.3^{* *}$ & 0.2 & -0.2 & -0.07 & 0.2 \\
\hline & $(0.5)$ & $(0.3)$ & $(0.1)$ & $(0.09)$ & $(0.2)$ \\
\hline \multirow[t]{2}{*}{ TL in $100 \mathrm{~km} \times$ Urban } & $2.5^{\star *}$ & -0.7 & 0.5 & 0.3 & 0.4 \\
\hline & $(1.3)$ & $(0.8)$ & $(0.4)$ & $(0.3)$ & $(0.6)$ \\
\hline Obs. & 2875 & 2875 & 2875 & 2875 & 2875 \\
\hline Adj. $R^{2}$ & 0.8 & 0.8 & 0.9 & 0.9 & 0.8 \\
\hline $\mathrm{KP} 1^{\text {st }} \mathrm{St} . \mathrm{F}$ & 2.1 & 2.0 & 2.1 & 1.5 & 2.2 \\
\hline \multirow[t]{2}{*}{ KP p-value } & 0.055 & 0.061 & 0.050 & 0.107 & 0.047 \\
\hline & Operatives & Professional & Service & Managerial & Non-Farm Lab. \\
\hline \multirow[t]{2}{*}{$\mathrm{TL}$ in $100 \mathrm{~km}$} & $1.5^{\star \star \star}$ & 0.1 & 0.1 & -0.2 & 0.06 \\
\hline & $(0.5)$ & $(0.09)$ & $(0.10)$ & $(0.1)$ & $(0.2)$ \\
\hline \multirow[t]{2}{*}{ TL in $100 \mathrm{~km} \times$ Urban } & $-2.2^{* *}$ & -0.05 & -0.3 & 0.6 & -0.7 \\
\hline & $(1.1)$ & $(0.3)$ & $(0.3)$ & $(0.4)$ & $(0.7)$ \\
\hline Obs. & 2875 & 2875 & 2875 & 2875 & 2875 \\
\hline Adj. $R^{2}$ & 0.5 & 0.7 & 0.9 & 0.6 & 0.5 \\
\hline $\mathrm{KP} 1^{\text {st }} \mathrm{St} . \mathrm{F}$ & 2.7 & 2.1 & 2.1 & 1.8 & 2.9 \\
\hline KP p-value & 0.032 & 0.059 & 0.059 & 0.078 & 0.026 \\
\hline
\end{tabular}

Notes: Regression of county occupation share on kilometers of high-voltage transmission lines (TL) and additional control variables discussed in the text, weighted by county population in 1910. Heteroskedasticity robust standard errors are reported in parentheses below each coefficient. Significance levels are indicated by ${ }^{*} p<0.1,{ }^{* *} p<0.05$, and ${ }^{* * *} p<0.01$. 
Table C.17: OLS: Effect of Electrification on Industries (1910-1920)

Percent of Male, Working Age Population (15-65) with Occupation in 1920

\begin{tabular}{|c|c|c|c|c|c|}
\hline & 1. Ag. & 2. Mining & 3. Const. & 4. Manu. & 5. Transp. \\
\hline TL in $100 \mathrm{~km}$ & $\begin{array}{c}-0.6^{\star *} \\
(0.3)\end{array}$ & $\begin{array}{r}-0.01 \\
(0.1)\end{array}$ & $\begin{array}{c}-0.02 \\
(0.1)\end{array}$ & $\begin{array}{c}0.1 \\
(0.2)\end{array}$ & $\begin{array}{l}-0.1 \\
(0.2)\end{array}$ \\
\hline $\begin{array}{l}\text { Obs. } \\
\text { Adj. } \mathrm{R}^{2}\end{array}$ & $\begin{array}{c}2895 \\
0.9\end{array}$ & $\begin{array}{c}2895 \\
0.8\end{array}$ & $\begin{array}{c}2895 \\
0.5\end{array}$ & $\begin{array}{c}2895 \\
0.9\end{array}$ & $\begin{array}{c}2895 \\
0.7\end{array}$ \\
\hline & 6. Trade. & 7. Fin. & 8. Serv. & 9. Pub. & 10. No Ind. \\
\hline TL in $100 \mathrm{~km}$ & $\begin{array}{l}0.2^{\star * *} \\
(0.05)\end{array}$ & $\begin{array}{c}0.04^{\star * *} \\
(0.01)\end{array}$ & $\begin{array}{l}0.2^{\star * *} \\
(0.06)\end{array}$ & $\begin{array}{l}0.008 \\
(0.08)\end{array}$ & $\begin{array}{c}0.7^{\star * *} \\
(0.1)\end{array}$ \\
\hline $\begin{array}{l}\text { Obs. } \\
\text { Adj. } R^{2}\end{array}$ & $\begin{array}{c}2895 \\
0.8\end{array}$ & $\begin{array}{c}2895 \\
0.7\end{array}$ & $\begin{array}{c}2895 \\
0.6\end{array}$ & $\begin{array}{c}2895 \\
0.0\end{array}$ & $\begin{array}{c}2895 \\
0.5\end{array}$ \\
\hline
\end{tabular}

Notes: Regression of county industry share on kilometers of high-voltage transmission lines (TL) and additional control variables discussed in the text, weighted by county population in 1910 . Heteroskedasticity robust standard errors are reported in parentheses below each coefficient. Significance levels are indicated by ${ }^{*} p<0.1,{ }^{* *} p<0.05$, and ${ }^{* * *} p<0.01$.

Table C.18: IV: Effect of Electrification on Industries (1910-1920)

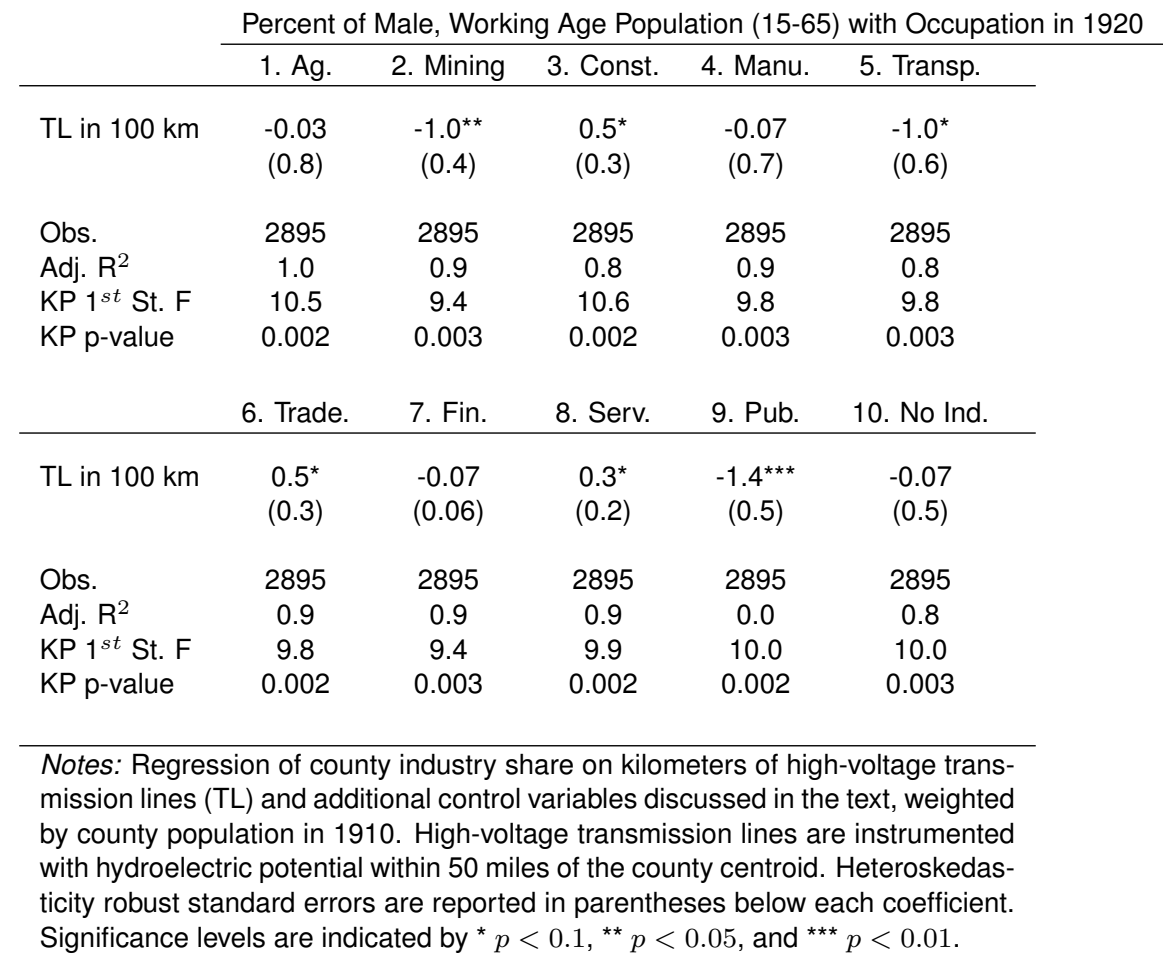


Table C.19: OLS: Effect of Electrification on Industries (1910-1930)

\begin{tabular}{|c|c|c|c|c|c|}
\hline & \multicolumn{5}{|c|}{ Percent of Male, Working Age Population (15-65) with Occupation in 1930} \\
\hline & 1. Ag. & 2. Mining & 3. Const. & 4. Manu. & 5. Transp. \\
\hline TL in $100 \mathrm{~km}$ & $\begin{array}{c}-1.0^{\star * *} \\
(0.2)\end{array}$ & $\begin{array}{l}0.3^{\star \star *} \\
(0.08)\end{array}$ & $\begin{array}{c}0.01 \\
(0.03)\end{array}$ & $\begin{array}{l}0.3^{\star \star *} \\
(0.08)\end{array}$ & $\begin{array}{c}0.05 \\
(0.05)\end{array}$ \\
\hline \multirow[t]{2}{*}{ Adj. $R^{2}$} & $\begin{array}{c}2895 \\
0.8\end{array}$ & $\begin{array}{c}2895 \\
0.7\end{array}$ & $\begin{array}{c}2895 \\
0.6\end{array}$ & $\begin{array}{c}2895 \\
0.7\end{array}$ & $\begin{array}{c}2895 \\
0.7\end{array}$ \\
\hline & 6. Trade. & 7. Fin. & 8. Serv. & 9. Pub. & 10. No Ind. \\
\hline TL in $100 \mathrm{~km}$ & $\begin{array}{l}0.2^{* * *} \\
(0.02)\end{array}$ & $\begin{array}{c}0.05^{\star \star \star} \\
(0.01)\end{array}$ & $\begin{array}{l}0.2^{* * *} \\
(0.04)\end{array}$ & $\begin{array}{l}0.03^{\star * *} \\
(0.008)\end{array}$ & $\begin{array}{l}0.2^{\star * *} \\
(0.05)\end{array}$ \\
\hline $\begin{array}{l}\text { Obs. } \\
\text { Adj. } R^{2}\end{array}$ & $\begin{array}{c}2895 \\
0.8\end{array}$ & $\begin{array}{c}2895 \\
0.6\end{array}$ & $\begin{array}{c}2895 \\
0.5\end{array}$ & $\begin{array}{c}2895 \\
0.5\end{array}$ & $\begin{array}{c}2895 \\
0.6\end{array}$ \\
\hline \multicolumn{6}{|c|}{$\begin{array}{l}\text { Notes: Regression of county industry share on kilometers of high-voltage trans- } \\
\text { mission lines }(T L) \text { and additional control variables discussed in the text, weighted } \\
\text { by county population in } 1910 \text {. Heteroskedasticity robust standard errors are re- } \\
\text { ported in parentheses below each coefficient. Significance levels are indicated } \\
\text { by }{ }^{*} p<0.1,{ }^{* \star} p<0.05 \text {, and }{ }^{* * *} p<0.01 \text {. }\end{array}$} \\
\hline
\end{tabular}

Table C.20: IV: Effect of Electrification on Industries (1910-1930)

\begin{tabular}{|c|c|c|c|c|c|}
\hline & \multicolumn{5}{|c|}{ Percent of Male, Working Age Population (15-65) with Occupation } \\
\hline & 1. Ag. & 2. Mining & 3. Const. & 4. Manu. & 5. Transp. \\
\hline TL in $100 \mathrm{~km}$ & $\begin{array}{l}-0.4 \\
(0.3)\end{array}$ & $\begin{array}{c}-0.1 \\
(0.10)\end{array}$ & $\begin{array}{c}0.05 \\
(0.08)\end{array}$ & $\begin{array}{l}0.5^{\star *} \\
(0.2)\end{array}$ & $\begin{array}{l}-0.1 \\
(0.1)\end{array}$ \\
\hline Obs. & 2895 & 2895 & 2895 & 2895 & 2895 \\
\hline Adj. $R^{2}$ & 0.9 & 0.8 & 0.8 & 0.9 & 0.8 \\
\hline $\mathrm{KP} 1^{s t}$ St. F & 27.9 & 22.8 & 26.0 & 24.7 & 25.0 \\
\hline KP p-value & 0.000 & 0.000 & 0.000 & 0.000 & 0.000 \\
\hline & 6. Trade. & 7. Fin. & 8. Serv. & 9. Pub. & 10. No Ind. \\
\hline TL in $100 \mathrm{~km}$ & $\begin{array}{c}0.06 \\
(0.08)\end{array}$ & $\begin{array}{l}-0.1^{* *} \\
(0.05)\end{array}$ & $\begin{array}{c}0.02 \\
(0.06)\end{array}$ & $\begin{array}{c}0.02 \\
(0.04)\end{array}$ & $\begin{array}{c}0.2 \\
(0.1)\end{array}$ \\
\hline Obs. & 2895 & 2895 & 2895 & 2895 & 2895 \\
\hline Adj. $R^{2}$ & 0.9 & 0.9 & 0.9 & 0.7 & 0.8 \\
\hline $\mathrm{KP} 1^{s t} \mathrm{St} . \mathrm{F}$ & 26.3 & 24.5 & 25.6 & 24.7 & 25.3 \\
\hline KP p-value & 0.000 & 0.000 & 0.000 & 0.000 & 0.000 \\
\hline
\end{tabular}

Notes: Regression of county industry share on kilometers of high-voltage transmission lines (TL) and additional control variables discussed in the text, weighted by county population in 1910. High-voltage transmission lines are instrumented with hydroelectric potential within 50 miles of the county centroid. Heteroskedasticity robust standard errors are reported in parentheses below each coefficient. Significance levels are indicated by ${ }^{*} p<0.1,{ }^{* *} p<0.05$, and ${ }^{* * *} p<0.01$. 
Table C.21: OLS/Urban/Rural: Effect of Electrification on Industries (1910-1940)

\begin{tabular}{|c|c|c|c|c|c|}
\hline & \multicolumn{5}{|c|}{ Percent of Male, Working Age Population (15-65) with Occupation in 1940} \\
\hline & 1. Ag. & 2. Mining & 3. Const. & 4. Manu. & 5. Transp. \\
\hline \multirow[t]{2}{*}{ TL in 100 km } & $-0.7^{* * *}$ & 0.02 & 0.06 & $0.4^{* * *}$ & $0.05^{*}$ \\
\hline & $(0.1)$ & $(0.05)$ & $(0.04)$ & $(0.08)$ & $(0.03)$ \\
\hline \multirow[t]{2}{*}{ TL in $100 \mathrm{~km} \times$ Urban } & 0.3 & -0.04 & $-0.3^{* * *}$ & -0.1 & -0.007 \\
\hline & $(0.2)$ & $(0.10)$ & $(0.10)$ & $(0.2)$ & $(0.06)$ \\
\hline Obs. & 2875 & 2875 & 2875 & 2875 & 2875 \\
\hline \multirow[t]{2}{*}{ Adj. $R^{2}$} & 0.8 & 0.6 & 0.2 & 0.7 & 0.7 \\
\hline & 6. Trade. & 7. Fin. & 8. Serv. & 9. Pub. & 10. No Ind. \\
\hline \multirow[t]{2}{*}{ TL in $100 \mathrm{~km}$} & $0.2^{\star \star \star}$ & $0.04^{\star \star *}$ & $0.2^{\star * \star}$ & 0.02 & $0.06^{\star * *}$ \\
\hline & $(0.03)$ & $(0.008)$ & $(0.04)$ & $(0.01)$ & $(0.02)$ \\
\hline \multirow[t]{2}{*}{ TL in $100 \mathrm{~km} \times$ Urban } & -0.0006 & 0.005 & $-0.2^{* *}$ & -0.04 & $-0.1^{* *}$ \\
\hline & $(0.10)$ & $(0.03)$ & $(0.1)$ & $(0.04)$ & $(0.05)$ \\
\hline Obs. & 2875 & 2875 & 2875 & 2875 & 2875 \\
\hline Adj. $R^{2}$ & 0.7 & 0.6 & 0.5 & 0.2 & 0.3 \\
\hline
\end{tabular}

Notes: Regression of county industry share on kilometers of high-voltage transmission lines (TL) and additional control variables discussed in the text, weighted by county population in 1910 . Heteroskedasticity robust standard errors are reported in parentheses below each coefficient. Significance levels are indicated by ${ }^{*} p<0.1,{ }^{* *} p<0.05$, and ${ }^{* * *} p<0.01$. 
Table C.22: IV/Urban/Rural: Effect of Electrification on Industries (1910-1940)

\begin{tabular}{|c|c|c|c|c|c|}
\hline & \multicolumn{5}{|c|}{ Percent of Male, Working Age Population (15-65) with Occupation in 1940} \\
\hline & 1. Ag. & 2. Mining & 3. Const. & 4. Manu. & 5. Transp. \\
\hline \multirow[t]{2}{*}{ TL in $100 \mathrm{~km}$} & $-1.1^{*}$ & 0.04 & $0.5^{\star *}$ & $1.4^{\star \star}$ & $-0.6^{* *}$ \\
\hline & $(0.6)$ & $(0.1)$ & $(0.2)$ & $(0.7)$ & $(0.3)$ \\
\hline \multirow[t]{2}{*}{ TL in $100 \mathrm{~km} \times$ Urban } & 1.5 & -0.06 & -1.1 & $-3.1^{*}$ & 1.2 \\
\hline & $(1.4)$ & $(0.3)$ & $(0.7)$ & $(1.9)$ & $(0.8)$ \\
\hline Obs. & 2875 & 2875 & 2875 & 2875 & 2875 \\
\hline Adj. $R^{2}$ & 0.9 & 0.7 & -0.1 & 0.7 & 0.4 \\
\hline $\mathrm{KP} 1^{\text {st }} \mathrm{St} . \mathrm{F}$ & 2.0 & 2.9 & 2.1 & 2.8 & 2.1 \\
\hline \multirow[t]{2}{*}{ KP p-value } & 0.061 & 0.027 & 0.059 & 0.028 & 0.055 \\
\hline & 6. Trade. & 7. Fin. & 8. Serv. & 9. Pub. & 10. No Ind. \\
\hline \multirow[t]{2}{*}{$\mathrm{TL}$ in $100 \mathrm{~km}$} & -0.3 & -0.009 & 0.1 & -0.2 & 0.02 \\
\hline & $(0.3)$ & $(0.06)$ & $(0.1)$ & $(0.1)$ & $(0.2)$ \\
\hline \multirow[t]{2}{*}{ TL in $100 \mathrm{~km} \mathrm{x} \mathrm{Urban}$} & 1.0 & -0.2 & -0.4 & 0.3 & 0.5 \\
\hline & $(0.8)$ & $(0.2)$ & $(0.4)$ & $(0.4)$ & $(0.5)$ \\
\hline Obs. & 2875 & 2875 & 2875 & 2875 & 2875 \\
\hline Adj. $\mathrm{R}^{2}$ & 0.8 & 0.8 & 0.8 & 0.4 & 0.2 \\
\hline $\mathrm{KP} 1^{\text {st }}$ St. F & 2.0 & 1.6 & 2.2 & 1.9 & 2.3 \\
\hline KP p-value & 0.062 & 0.103 & 0.053 & 0.070 & 0.045 \\
\hline
\end{tabular}




\section{Appendix C.3. Distribution of Occupations \& Industries}

Table C.23: Distribution of Occupations Within Industries

Occupation's Share within Industry (\%): Male, Working Age Population with Occupation

\begin{tabular}{|c|c|c|c|c|c|c|c|c|c|c|c|c|c|}
\hline & Sum & Prof. & Farm. & Man. & Cler. & Sales & Craft & Oper. & Serv. & F Lab & NF Lab & Mil. & No Occ. \\
\hline \multicolumn{14}{|l|}{ A. 1910} \\
\hline Agriculture & 100.0 & 0.1 & 64.0 & 0.0 & 0.0 & 0.0 & 0.0 & 0.0 & 0.0 & 35.0 & 0.9 & 0.0 & 0.0 \\
\hline Mining & 100.0 & 0.1 & 0.0 & 0.8 & 0.6 & 0.0 & 5.3 & 92.8 & 0.1 & 0.0 & 0.2 & 0.0 & 0.0 \\
\hline Construction & 100.0 & 0.1 & 0.0 & 5.2 & 0.3 & 0.0 & 76.5 & 1.4 & 0.1 & 0.0 & 16.3 & 0.0 & 0.0 \\
\hline Manufacturing & 100.0 & 1.1 & 0.0 & 2.4 & 3.2 & 0.2 & 29.4 & 27.9 & 0.8 & 0.0 & 35.0 & 0.0 & 0.0 \\
\hline Transportation & 100.0 & 0.7 & 0.0 & 6.9 & 11.0 & 0.2 & 21.7 & 17.7 & 2.2 & 0.0 & 39.5 & 0.0 & 0.0 \\
\hline Trade & 100.0 & 2.1 & 0.0 & 29.9 & 3.7 & 32.8 & 8.4 & 9.3 & 8.6 & 0.0 & 5.1 & 0.0 & 0.0 \\
\hline Finance & 100.0 & 0.9 & 0.0 & 16.4 & 24.5 & 44.5 & 1.1 & 0.6 & 10.2 & 0.0 & 1.8 & 0.0 & 0.0 \\
\hline Service & 100.0 & 36.6 & 0.0 & 4.2 & 5.9 & 0.4 & 14.9 & 6.5 & 28.0 & 0.0 & 3.5 & 0.0 & 0.0 \\
\hline Public Sector & 100.0 & 2.8 & 0.0 & 7.8 & 40.5 & 0.0 & 2.2 & 1.3 & 31.1 & 0.0 & 14.4 & 0.0 & 0.0 \\
\hline No Industry & 100.0 & 1.5 & 0.0 & 12.9 & 6.9 & 7.3 & 12.4 & 9.7 & 2.4 & 0.0 & 46.8 & 0.0 & 0.0 \\
\hline \multicolumn{14}{|l|}{ B. 1920} \\
\hline Agriculture & 100.0 & 0.1 & 68.4 & 0.0 & 0.0 & 0.0 & 0.1 & 0.1 & 0.0 & 30.1 & 1.2 & 0.0 & 0.0 \\
\hline Mining & 100.0 & 0.4 & 0.0 & 1.5 & 0.9 & 0.0 & 8.0 & 86.0 & 0.2 & 0.0 & 2.9 & 0.0 & 0.0 \\
\hline Construction & 100.0 & 0.6 & 0.0 & 7.0 & 0.4 & 0.0 & 74.2 & 1.2 & 0.1 & 0.0 & 16.3 & 0.0 & 0.0 \\
\hline Manufacturing & 100.0 & 1.4 & 0.0 & 2.6 & 4.3 & 0.3 & 31.2 & 26.7 & 1.0 & 0.0 & 32.5 & 0.0 & 0.0 \\
\hline Transportation & 100.0 & 1.2 & 0.0 & 6.1 & 11.1 & 0.1 & 24.3 & 22.7 & 2.6 & 0.0 & 31.9 & 0.0 & 0.0 \\
\hline Trade & 100.0 & 2.2 & 0.0 & 31.3 & 3.6 & 32.8 & 7.6 & 9.2 & 6.3 & 0.0 & 7.0 & 0.0 & 0.0 \\
\hline Finance & 100.0 & 2.0 & 0.0 & 21.2 & 25.2 & 40.0 & 1.1 & 0.6 & 8.3 & 0.0 & 1.7 & 0.0 & 0.0 \\
\hline Service & 100.0 & 32.9 & 0.0 & 5.9 & 5.7 & 0.6 & 20.9 & 7.4 & 22.7 & 0.0 & 4.0 & 0.0 & 0.0 \\
\hline Public Sector & 100.0 & 2.7 & 0.0 & 6.0 & 27.8 & 0.0 & 1.5 & 1.4 & 20.6 & 0.0 & 11.3 & 28.7 & 0.0 \\
\hline No Industry & 100.0 & 5.2 & 3.1 & 10.6 & 9.9 & 4.1 & 16.6 & 20.4 & 5.5 & 1.5 & 22.5 & 0.6 & 0.0 \\
\hline \multicolumn{14}{|l|}{ C. 1930} \\
\hline Agriculture & 100.0 & 0.1 & 62.4 & 0.1 & 0.0 & 0.0 & 0.1 & 0.2 & 0.0 & 35.8 & 1.4 & 0.0 & 0.0 \\
\hline Mining & 100.0 & 0.9 & 0.0 & 1.8 & 0.8 & 0.1 & 9.9 & 86.1 & 0.3 & 0.0 & 0.2 & 0.0 & 0.0 \\
\hline Construction & 100.0 & 1.4 & 0.0 & 6.7 & 0.6 & 0.1 & 63.6 & 2.7 & 0.2 & 0.0 & 24.7 & 0.0 & 0.0 \\
\hline Manufacturing & 100.0 & 2.3 & 0.0 & 3.3 & 4.9 & 1.1 & 28.2 & 28.8 & 1.1 & 0.0 & 30.3 & 0.0 & 0.0 \\
\hline Transportation & 100.0 & 2.1 & 0.0 & 6.3 & 12.4 & 0.4 & 24.4 & 25.5 & 2.8 & 0.0 & 26.2 & 0.0 & 0.0 \\
\hline Trade & 100.0 & 2.4 & 0.0 & 29.6 & 3.4 & 35.8 & 4.8 & 12.0 & 7.4 & 0.0 & 4.5 & 0.0 & 0.0 \\
\hline Finance & 100.0 & 2.3 & 0.0 & 17.1 & 24.0 & 42.2 & 0.9 & 0.6 & 11.1 & 0.0 & 1.8 & 0.0 & 0.0 \\
\hline Service & 100.0 & 29.2 & 0.0 & 6.8 & 4.6 & 1.2 & 21.4 & 7.9 & 22.8 & 0.0 & 6.0 & 0.0 & 0.0 \\
\hline Public Sector & 100.0 & 4.6 & 0.0 & 7.4 & 35.0 & 0.1 & 2.8 & 3.5 & 32.8 & 0.0 & 13.7 & 0.1 & 0.0 \\
\hline No Industry & 100.0 & 5.6 & 1.4 & 10.1 & 6.8 & 4.8 & 15.8 & 20.9 & 4.3 & 0.8 & 29.3 & 0.3 & 0.0 \\
\hline \multicolumn{14}{|l|}{ B. 1940} \\
\hline Agriculture & 100.0 & 0.7 & 56.4 & 0.3 & 0.1 & 0.0 & 0.3 & 0.7 & 0.1 & 38.4 & 3.1 & 0.0 & 0.0 \\
\hline Mining & 100.0 & 1.2 & 0.0 & 1.4 & 0.7 & 0.0 & 9.6 & 86.5 & 0.3 & 0.0 & 0.2 & 0.0 & 0.0 \\
\hline Construction & 100.0 & 2.9 & 0.1 & 2.8 & 1.7 & 0.1 & 39.2 & 6.1 & 0.7 & 0.1 & 46.3 & 0.0 & 0.0 \\
\hline Manufacturing & 100.0 & 3.2 & 0.0 & 4.5 & 7.5 & 3.8 & 22.8 & 38.3 & 1.6 & 0.0 & 18.2 & 0.0 & 0.0 \\
\hline Transportation & 100.0 & 2.1 & 0.0 & 6.3 & 13.4 & 0.7 & 23.1 & 34.4 & 2.9 & 0.0 & 17.2 & 0.0 & 0.0 \\
\hline Trade & 100.0 & 1.7 & 0.0 & 30.8 & 6.1 & 25.4 & 5.7 & 16.5 & 10.3 & 0.0 & 3.5 & 0.0 & 0.0 \\
\hline Finance & 100.0 & 0.7 & 0.0 & 22.3 & 26.1 & 33.2 & 1.5 & 0.5 & 14.0 & 0.0 & 1.9 & 0.0 & 0.0 \\
\hline Service & 100.0 & 32.0 & 0.0 & 6.3 & 5.3 & 1.0 & 16.3 & 8.8 & 26.8 & 0.0 & 3.6 & 0.0 & 0.0 \\
\hline Public Sector & 100.0 & 10.9 & 0.0 & 15.9 & 39.6 & 0.2 & 4.9 & 1.5 & 25.2 & 0.0 & 1.9 & 0.0 & 0.0 \\
\hline No Industry & 100.0 & 10.6 & 2.4 & 6.4 & 11.6 & 5.9 & 11.9 & 14.6 & 5.7 & 2.5 & 28.4 & 0.0 & 0.0 \\
\hline
\end{tabular}

Notes: The table reports the fraction of each occupation within nine broad sectors. "No Industry" refers to individuals who do not work in a specific industry or where information on industry was not reported. The underlying population includes male, working age (16-65) individuals with a reported occupation. 
Table C.24: Distribution of Industries Within Occupations: Male, Working Age Population with Occupation

\begin{tabular}{|c|c|c|c|c|c|c|c|c|c|c|c|}
\hline & \multicolumn{11}{|c|}{ Industry's Share within Occupation (\%): Male, Working Age Population with Occupation } \\
\hline & Sum & Ag. & Min. & Con. & Man. & Trans. & Trade & Fin. & Serv. & Pub. & No Ind. \\
\hline \multicolumn{12}{|l|}{ A. 1910} \\
\hline Professional & 100.0 & 0.7 & 0.2 & 0.3 & 5.6 & 1.9 & 6.7 & 0.4 & 78.6 & 1.0 & 4.6 \\
\hline Farmer & 100.0 & 100.0 & 0.0 & 0.0 & 0.0 & 0.0 & 0.0 & 0.0 & 0.0 & 0.0 & 0.0 \\
\hline Manager & 100.0 & 0.0 & 0.5 & 5.8 & 6.3 & 9.8 & 47.7 & 4.0 & 4.6 & 1.4 & 19.8 \\
\hline Clerical & 100.0 & 0.0 & 0.6 & 0.5 & 13.5 & 25.8 & 9.8 & 9.9 & 10.5 & 11.9 & 17.5 \\
\hline Sales & 100.0 & 0.0 & 0.0 & 0.0 & 0.8 & 0.4 & 69.1 & 14.4 & 0.5 & 0.0 & 14.8 \\
\hline Craft & 100.0 & 0.1 & 1.3 & 34.9 & 31.0 & 12.6 & 5.5 & 0.1 & 6.6 & 0.2 & 7.8 \\
\hline Operative & 100.0 & 0.1 & 29.1 & 0.8 & 37.5 & 13.1 & 7.7 & 0.1 & 3.7 & 0.1 & 7.7 \\
\hline Service & 100.0 & 0.1 & 0.1 & 0.1 & 3.2 & 5.2 & 22.5 & 4.1 & 49.7 & 9.0 & 6.0 \\
\hline Farm Laborer & 100.0 & 100.0 & 0.0 & 0.0 & 0.0 & 0.0 & 0.0 & 0.0 & 0.0 & 0.0 & 0.0 \\
\hline Non-Farm Laborer & 100.0 & 2.0 & 0.0 & 7.1 & 35.2 & 21.8 & 3.2 & 0.2 & 1.5 & 1.0 & 28.0 \\
\hline \multicolumn{12}{|l|}{ B. 1920} \\
\hline Professional & 100.0 & 0.7 & 0.4 & 1.0 & 7.1 & 3.0 & 5.8 & 1.0 & 63.5 & 1.5 & 16.0 \\
\hline Farmer & 100.0 & 98.4 & 0.0 & 0.0 & 0.0 & 0.0 & 0.0 & 0.0 & 0.0 & 0.0 & 1.6 \\
\hline Manager & 100.0 & 0.2 & 0.9 & 5.9 & 7.3 & 8.5 & 45.3 & 5.6 & 6.3 & 1.8 & 18.2 \\
\hline Clerical & 100.0 & 0.1 & 0.7 & 0.5 & 17.0 & 21.4 & 7.2 & 9.3 & 8.4 & 11.8 & 23.5 \\
\hline Sales & 100.0 & 0.0 & 0.0 & 0.0 & 1.5 & 0.3 & 70.9 & 15.8 & 0.9 & 0.0 & 10.5 \\
\hline Craft & 100.0 & 0.1 & 1.8 & 24.9 & 35.2 & 13.3 & 4.4 & 0.1 & 8.8 & 0.2 & 11.2 \\
\hline Operative & 100.0 & 0.2 & 22.8 & 0.5 & 35.4 & 14.7 & 6.2 & 0.1 & 3.7 & 0.2 & 16.3 \\
\hline Service & 100.0 & 0.1 & 0.2 & 0.2 & 4.7 & 6.1 & 15.9 & 3.8 & 42.0 & 10.8 & 16.2 \\
\hline Farm Laborer & 100.0 & 98.3 & 0.0 & 0.0 & 0.0 & 0.0 & 0.0 & 0.0 & 0.0 & 0.0 & 1.7 \\
\hline Non-Farm Laborer & 100.0 & 2.6 & 0.8 & 6.5 & 43.2 & 20.6 & 4.7 & 0.2 & 2.0 & 1.6 & 17.9 \\
\hline Military & 100.0 & 0.0 & 0.0 & 0.0 & 0.0 & 0.0 & 0.0 & 0.0 & 0.0 & 89.3 & 10.7 \\
\hline \multicolumn{12}{|l|}{ C. 1930} \\
\hline Professional & 100.0 & 0.6 & 0.6 & 2.3 & 8.8 & 3.7 & 6.4 & 1.5 & 59.7 & 1.8 & 14.7 \\
\hline Farmer & 100.0 & 99.1 & 0.0 & 0.0 & 0.0 & 0.0 & 0.0 & 0.0 & 0.0 & 0.0 & 0.9 \\
\hline Manager & 100.0 & 0.2 & 0.7 & 6.7 & 7.6 & 6.6 & 46.0 & 6.4 & 8.2 & 1.7 & 15.8 \\
\hline Clerical & 100.0 & 0.1 & 0.5 & 1.0 & 17.7 & 20.6 & 8.3 & 14.0 & 8.7 & 12.5 & 16.6 \\
\hline Sales & 100.0 & 0.0 & 0.0 & 0.1 & 2.9 & 0.5 & 66.8 & 18.8 & 1.8 & 0.0 & 9.0 \\
\hline Craft & 100.0 & 0.1 & 1.9 & 29.1 & 29.8 & 11.9 & 3.5 & 0.1 & 11.9 & 0.3 & 11.4 \\
\hline Operative & 100.0 & 0.3 & 18.4 & 1.4 & 34.1 & 13.9 & 9.6 & 0.1 & 4.9 & 0.4 & 16.8 \\
\hline Service & 100.0 & 0.1 & 0.2 & 0.3 & 4.1 & 4.7 & 18.1 & 6.5 & 43.6 & 11.8 & 10.7 \\
\hline Farm Laborer & 100.0 & 99.1 & 0.0 & 0.0 & 0.0 & 0.0 & 0.0 & 0.0 & 0.0 & 0.0 & 0.9 \\
\hline Non-Farm Laborer & 100.0 & 2.6 & 0.0 & 12.9 & 36.5 & 14.5 & 3.7 & 0.3 & 3.8 & 1.6 & 23.9 \\
\hline Military & 100.0 & 0.0 & 0.0 & 0.0 & 0.0 & 0.0 & 0.0 & 0.0 & 0.0 & 4.1 & 95.9 \\
\hline \multicolumn{12}{|l|}{ B. 1940} \\
\hline Professional & 100.0 & 2.6 & 0.5 & 5.9 & 12.8 & 2.7 & 4.6 & 0.3 & 57.9 & 5.7 & 7.1 \\
\hline Farmer & 100.0 & 99.1 & 0.0 & 0.1 & 0.0 & 0.0 & 0.0 & 0.0 & 0.0 & 0.0 & 0.8 \\
\hline Manager & 100.0 & 0.7 & 0.4 & 3.8 & 12.1 & 5.2 & 55.4 & 6.4 & 7.6 & 5.5 & 2.8 \\
\hline Clerical & 100.0 & 0.3 & 0.3 & 3.1 & 25.9 & 14.3 & 14.2 & 9.6 & 8.2 & 17.7 & 6.6 \\
\hline Sales & 100.0 & 0.1 & 0.0 & 0.2 & 14.7 & 0.8 & 65.2 & 13.5 & 1.7 & 0.1 & 3.8 \\
\hline Craft & 100.0 & 0.4 & 1.6 & 30.6 & 35.1 & 11.0 & 5.8 & 0.2 & 11.2 & 1.0 & 3.0 \\
\hline Operative & 100.0 & 0.8 & 11.8 & 3.9 & 48.0 & 13.4 & 13.9 & 0.1 & 5.0 & 0.2 & 3.0 \\
\hline Service & 100.0 & 0.3 & 0.1 & 1.4 & 5.9 & 3.3 & 24.9 & 5.4 & 43.5 & 11.8 & 3.4 \\
\hline Farm Laborer & 100.0 & 98.7 & 0.0 & 0.1 & 0.0 & 0.0 & 0.0 & 0.0 & 0.0 & 0.0 & 1.1 \\
\hline Non-Farm Laborer & 100.0 & 4.9 & 0.0 & 39.9 & 30.8 & 9.0 & 4.0 & 0.3 & 2.7 & 0.4 & 7.9 \\
\hline
\end{tabular}

Notes: The table reports the fraction of each industry within ten broad occupation groups. "No Industry" refers to individuals who do not work in a specific industry or where information on industry was not reported. The underlying population includes male, working age (16-65) individuals with a reported occupation. 
Table C.25: Distribution of Occupations Within Industries

Occupation's Share within Industry (\%): Male, Working Age Population

\begin{tabular}{|c|c|c|c|c|c|c|c|c|c|c|c|c|c|}
\hline & Sum & Prof. & Farm. & Man. & Cler. & Sales & Craft & Oper. & Serv. & F Lab & NF Lab & Mil. & No Occ. \\
\hline \multicolumn{14}{|l|}{ A. 1910} \\
\hline Agriculture & 100.0 & 0.1 & 63.7 & 0.0 & 0.0 & 0.0 & 0.1 & 0.0 & 0.0 & 35.2 & 0.9 & 0.0 & 0.0 \\
\hline Mining & 100.0 & 0.2 & 0.0 & 1.0 & 0.7 & 0.0 & 5.8 & 91.9 & 0.2 & 0.0 & 0.2 & 0.0 & 0.0 \\
\hline Construction & 100.0 & 0.3 & 0.0 & 5.3 & 0.3 & 0.0 & 76.0 & 1.5 & 0.1 & 0.0 & 16.5 & 0.0 & 0.0 \\
\hline Manufacturing & 100.0 & 1.2 & 0.0 & 2.5 & 3.5 & 0.3 & 29.4 & 28.1 & 0.8 & 0.0 & 34.1 & 0.0 & 0.0 \\
\hline Transportation & 100.0 & 0.8 & 0.0 & 6.9 & 11.4 & 0.2 & 21.8 & 17.9 & 2.3 & 0.0 & 38.8 & 0.0 & 0.0 \\
\hline Trade & 100.0 & 2.2 & 0.0 & 29.9 & 4.0 & 32.3 & 8.5 & 9.4 & 8.5 & 0.0 & 5.2 & 0.0 & 0.0 \\
\hline Finance & 100.0 & 1.0 & 0.0 & 16.5 & 24.7 & 44.1 & 1.2 & 0.7 & 10.0 & 0.0 & 1.8 & 0.0 & 0.0 \\
\hline Service & 100.0 & 36.1 & 0.0 & 4.4 & 5.9 & 0.4 & 15.0 & 6.6 & 27.8 & 0.0 & 3.7 & 0.0 & 0.0 \\
\hline Public Sector & 100.0 & 2.6 & 0.0 & 7.3 & 32.2 & 0.0 & 1.8 & 1.1 & 25.2 & 0.0 & 11.3 & 18.5 & 0.0 \\
\hline No Industry & 100.0 & 1.8 & 0.9 & 6.2 & 4.9 & 3.5 & 7.8 & 8.7 & 2.3 & 0.6 & 17.5 & 0.1 & 45.8 \\
\hline \multicolumn{14}{|l|}{ B. 1920} \\
\hline Agriculture & 100.0 & 0.1 & 68.4 & 0.0 & 0.0 & 0.0 & 0.1 & 0.1 & 0.0 & 30.1 & 1.2 & 0.0 & 0.0 \\
\hline Mining & 100.0 & 0.4 & 0.0 & 1.5 & 0.9 & 0.0 & 8.0 & 86.0 & 0.2 & 0.0 & 2.9 & 0.0 & 0.0 \\
\hline Construction & 100.0 & 0.6 & 0.0 & 7.0 & 0.4 & 0.0 & 74.2 & 1.2 & 0.1 & 0.0 & 16.3 & 0.0 & 0.0 \\
\hline Manufacturing & 100.0 & 1.4 & 0.0 & 2.6 & 4.3 & 0.3 & 31.2 & 26.7 & 1.0 & 0.0 & 32.5 & 0.0 & 0.0 \\
\hline Transportation & 100.0 & 1.2 & 0.0 & 6.1 & 11.1 & 0.1 & 24.3 & 22.7 & 2.6 & 0.0 & 31.9 & 0.0 & 0.0 \\
\hline Trade & 100.0 & 2.2 & 0.0 & 31.3 & 3.6 & 32.8 & 7.6 & 9.2 & 6.3 & 0.0 & 7.0 & 0.0 & 0.0 \\
\hline Finance & 100.0 & 2.0 & 0.0 & 21.2 & 25.2 & 40.0 & 1.1 & 0.6 & 8.3 & 0.0 & 1.7 & 0.0 & 0.0 \\
\hline Service & 100.0 & 32.9 & 0.0 & 5.9 & 5.7 & 0.6 & 20.9 & 7.4 & 22.7 & 0.0 & 4.0 & 0.0 & 0.0 \\
\hline Public Sector & 100.0 & 2.7 & 0.0 & 6.0 & 27.8 & 0.0 & 1.5 & 1.4 & 20.6 & 0.0 & 11.3 & 28.7 & 0.0 \\
\hline No Industry & 100.0 & 1.6 & 1.0 & 3.3 & 3.1 & 1.3 & 5.2 & 6.4 & 1.7 & 0.5 & 7.0 & 0.2 & 68.9 \\
\hline \multicolumn{14}{|l|}{ C. 1930} \\
\hline Agriculture & 100.0 & 0.1 & 62.4 & 0.1 & 0.0 & 0.0 & 0.1 & 0.2 & 0.0 & 35.8 & 1.4 & 0.0 & 0.0 \\
\hline Mining & 100.0 & 0.9 & 0.0 & 1.8 & 0.8 & 0.1 & 9.9 & 86.1 & 0.3 & 0.0 & 0.2 & 0.0 & 0.0 \\
\hline Construction & 100.0 & 1.4 & 0.0 & 6.7 & 0.6 & 0.1 & 63.6 & 2.7 & 0.2 & 0.0 & 24.7 & 0.0 & 0.0 \\
\hline Manufacturing & 100.0 & 2.3 & 0.0 & 3.3 & 4.9 & 1.1 & 28.2 & 28.8 & 1.1 & 0.0 & 30.3 & 0.0 & 0.0 \\
\hline Transportation & 100.0 & 2.1 & 0.0 & 6.3 & 12.4 & 0.4 & 24.3 & 25.5 & 2.8 & 0.0 & 26.2 & 0.0 & 0.0 \\
\hline Trade & 100.0 & 2.4 & 0.0 & 29.6 & 3.4 & 35.8 & 4.8 & 12.0 & 7.4 & 0.0 & 4.5 & 0.0 & 0.0 \\
\hline Finance & 100.0 & 2.3 & 0.0 & 17.1 & 24.0 & 42.2 & 0.9 & 0.6 & 11.1 & 0.0 & 1.8 & 0.0 & 0.0 \\
\hline Service & 100.0 & 29.2 & 0.0 & 6.8 & 4.6 & 1.2 & 21.4 & 7.9 & 22.8 & 0.0 & 6.0 & 0.0 & 0.0 \\
\hline Public Sector & 100.0 & 3.8 & 0.0 & 6.1 & 28.8 & 0.1 & 2.3 & 2.9 & 27.0 & 0.0 & 11.3 & 17.9 & 0.0 \\
\hline No Industry & 100.0 & 1.6 & 0.4 & 2.9 & 2.0 & 1.4 & 4.5 & 6.0 & 1.3 & 0.2 & 8.3 & 0.1 & 71.2 \\
\hline \multicolumn{14}{|l|}{ B. 1940} \\
\hline Agriculture & 100.0 & 0.7 & 56.0 & 0.3 & 0.1 & 0.0 & 0.3 & 0.7 & 0.1 & 38.7 & 3.1 & 0.0 & 0.0 \\
\hline Mining & 100.0 & 1.2 & 0.0 & 1.4 & 0.7 & 0.0 & 9.5 & 86.7 & 0.3 & 0.0 & 0.2 & 0.0 & 0.0 \\
\hline Construction & 100.0 & 2.9 & 0.1 & 2.8 & 1.7 & 0.1 & 39.2 & 6.0 & 0.7 & 0.1 & 46.4 & 0.0 & 0.0 \\
\hline Manufacturing & 100.0 & 3.2 & 0.0 & 4.5 & 7.5 & 3.9 & 22.8 & 38.3 & 1.6 & 0.0 & 18.3 & 0.0 & 0.0 \\
\hline Transportation & 100.0 & 2.1 & 0.0 & 6.3 & 13.3 & 0.6 & 23.0 & 34.4 & 2.9 & 0.0 & 17.3 & 0.0 & 0.0 \\
\hline Trade & 100.0 & 1.7 & 0.0 & 30.7 & 6.1 & 25.4 & 5.7 & 16.5 & 10.3 & 0.0 & 3.5 & 0.0 & 0.0 \\
\hline Finance & 100.0 & 0.7 & 0.0 & 22.3 & 26.0 & 33.2 & 1.4 & 0.5 & 14.0 & 0.0 & 1.9 & 0.0 & 0.0 \\
\hline Service & 100.0 & 32.6 & 0.0 & 6.2 & 5.2 & 1.0 & 16.0 & 8.7 & 26.9 & 0.0 & 3.5 & 0.0 & 0.0 \\
\hline Public Sector & 100.0 & 9.0 & 0.0 & 13.0 & 32.3 & 0.1 & 4.0 & 1.2 & 20.6 & 0.0 & 1.5 & 18.3 & 0.0 \\
\hline No Industry & 100.0 & 2.2 & 0.6 & 1.3 & 2.4 & 1.2 & 2.5 & 3.1 & 1.2 & 0.6 & 6.0 & 0.0 & 78.8 \\
\hline
\end{tabular}

Notes: The table reports the fraction of each occupation within nine broad sectors. "No Industry" refers to individuals who do not work in a specific industry or where information on industry was not reported. The underlying population includes male, working age (16-65) individuals. 
Table C.26: Distribution of Industries Within Occupations: Male, Working Age Population

\begin{tabular}{|c|c|c|c|c|c|c|c|c|c|c|c|}
\hline & \multirow[b]{2}{*}{ Sum } & \multicolumn{10}{|c|}{ Industry's Share within Occupation (\%) } \\
\hline & & Ag. & Min. & Con. & Man. & Trans. & Trade & Fin. & Serv. & Pub. & No Ind. \\
\hline \multicolumn{12}{|l|}{ A. 1910} \\
\hline Professional & 100.0 & 0.8 & 0.2 & 0.5 & 5.4 & 1.9 & 5.9 & 0.4 & 68.0 & 1.0 & 15.9 \\
\hline Farmer & 100.0 & 98.8 & 0.0 & 0.0 & 0.0 & 0.0 & 0.0 & 0.0 & 0.0 & 0.0 & 1.2 \\
\hline Manager & 100.0 & 0.0 & 0.5 & 5.2 & 5.8 & 8.7 & 42.3 & 3.7 & 4.2 & 1.5 & 28.0 \\
\hline Clerical & 100.0 & 0.0 & 0.5 & 0.5 & 11.8 & 20.7 & 8.2 & 7.9 & 8.4 & 9.4 & 32.5 \\
\hline Sales & 100.0 & 0.0 & 0.0 & 0.0 & 0.8 & 0.4 & 63.0 & 13.5 & 0.6 & 0.0 & 21.7 \\
\hline Craft & 100.0 & 0.1 & 1.3 & 31.7 & 28.8 & 11.6 & 5.1 & 0.1 & 6.2 & 0.2 & 15.0 \\
\hline Operative & 100.0 & 0.1 & 24.5 & 0.8 & 33.0 & 11.4 & 6.8 & 0.1 & 3.3 & 0.1 & 20.1 \\
\hline Service & 100.0 & 0.1 & 0.2 & 0.1 & 3.0 & 4.7 & 19.5 & 3.6 & 43.7 & 8.2 & 17.0 \\
\hline Farm Laborer & 100.0 & 98.4 & 0.0 & 0.0 & 0.0 & 0.0 & 0.0 & 0.0 & 0.0 & 0.0 & 1.6 \\
\hline Non-Farm Laborer & 100.0 & 1.9 & 0.0 & 6.7 & 32.6 & 20.2 & 3.1 & 0.2 & 1.5 & 1.0 & 32.8 \\
\hline Military & 100.0 & 0.0 & 0.0 & 0.0 & 0.0 & 0.0 & 0.0 & 0.0 & 0.0 & 89.8 & 10.2 \\
\hline No Occupation & 100.0 & 0.0 & 0.0 & 0.0 & 0.0 & 0.0 & 0.0 & 0.0 & 0.0 & 0.0 & 100.0 \\
\hline \multicolumn{12}{|l|}{ B. 1920} \\
\hline Professional & 100.0 & 0.7 & 0.4 & 1.0 & 7.1 & 3.0 & 5.8 & 1.0 & 63.5 & 1.5 & 16.0 \\
\hline Farmer & 100.0 & 98.4 & 0.0 & 0.0 & 0.0 & 0.0 & 0.0 & 0.0 & 0.0 & 0.0 & 1.6 \\
\hline Manager & 100.0 & 0.2 & 0.9 & 5.9 & 7.3 & 8.5 & 45.3 & 5.6 & 6.3 & 1.8 & 18.2 \\
\hline Clerical & 100.0 & 0.1 & 0.7 & 0.5 & 17.0 & 21.4 & 7.2 & 9.3 & 8.4 & 11.8 & 23.5 \\
\hline Sales & 100.0 & 0.0 & 0.0 & 0.0 & 1.5 & 0.3 & 70.9 & 15.8 & 0.9 & 0.0 & 10.5 \\
\hline Craft & 100.0 & 0.1 & 1.8 & 24.9 & 35.2 & 13.3 & 4.4 & 0.1 & 8.8 & 0.2 & 11.2 \\
\hline Operative & 100.0 & 0.2 & 22.8 & 0.5 & 35.4 & 14.7 & 6.2 & 0.1 & 3.7 & 0.2 & 16.3 \\
\hline Service & 100.0 & 0.1 & 0.2 & 0.2 & 4.7 & 6.1 & 15.9 & 3.8 & 42.0 & 10.8 & 16.2 \\
\hline Farm Laborer & 100.0 & 98.3 & 0.0 & 0.0 & 0.0 & 0.0 & 0.0 & 0.0 & 0.0 & 0.0 & 1.7 \\
\hline Non-Farm Laborer & 100.0 & 2.6 & 0.8 & 6.5 & 43.2 & 20.6 & 4.7 & 0.2 & 2.0 & 1.6 & 17.9 \\
\hline Military & 100.0 & 0.0 & 0.0 & 0.0 & 0.0 & 0.0 & 0.0 & 0.0 & 0.0 & 89.3 & 10.7 \\
\hline No Occupation & 100.0 & 0.0 & 0.0 & 0.0 & 0.0 & 0.0 & 0.0 & 0.0 & 0.0 & 0.0 & 100.0 \\
\hline \multicolumn{12}{|l|}{ C. 1930} \\
\hline Professional & 100.0 & 0.6 & 0.6 & 2.3 & 8.8 & 3.7 & 6.3 & 1.4 & 59.4 & 1.8 & 15.0 \\
\hline Farmer & 100.0 & 99.0 & 0.0 & 0.0 & 0.0 & 0.0 & 0.0 & 0.0 & 0.0 & 0.0 & 1.0 \\
\hline Manager & 100.0 & 0.2 & 0.7 & 6.7 & 7.6 & 6.6 & 45.8 & 6.3 & 8.2 & 1.7 & 16.1 \\
\hline Clerical & 100.0 & 0.1 & 0.5 & 1.0 & 17.7 & 20.5 & 8.3 & 13.9 & 8.7 & 12.5 & 16.9 \\
\hline Sales & 100.0 & 0.0 & 0.0 & 0.1 & 2.9 & 0.5 & 66.7 & 18.8 & 1.8 & 0.0 & 9.1 \\
\hline Craft & 100.0 & 0.1 & 1.9 & 29.1 & 29.8 & 11.8 & 3.4 & 0.1 & 11.9 & 0.3 & 11.5 \\
\hline Operative & 100.0 & 0.3 & 18.4 & 1.4 & 34.0 & 13.9 & 9.6 & 0.1 & 4.9 & 0.4 & 17.0 \\
\hline Service & 100.0 & 0.1 & 0.2 & 0.3 & 4.1 & 4.7 & 18.1 & 6.5 & 43.5 & 11.8 & 10.9 \\
\hline Farm Laborer & 100.0 & 99.0 & 0.0 & 0.0 & 0.0 & 0.0 & 0.0 & 0.0 & 0.0 & 0.0 & 1.0 \\
\hline Non-Farm Laborer & 100.0 & 2.6 & 0.0 & 12.9 & 36.4 & 14.5 & 3.7 & 0.3 & 3.8 & 1.6 & 24.1 \\
\hline Military & 100.0 & 0.1 & 0.0 & 0.0 & 0.0 & 0.0 & 0.0 & 0.0 & 0.0 & 91.7 & 8.2 \\
\hline No Occupation & 100.0 & 0.0 & 0.0 & 0.0 & 0.0 & 0.0 & 0.0 & 0.0 & 0.0 & 0.0 & 100.0 \\
\hline \multicolumn{12}{|l|}{ B. 1940} \\
\hline Professional & 100.0 & 2.6 & 0.5 & 5.9 & 12.5 & 2.6 & 4.5 & 0.3 & 58.4 & 5.6 & 7.1 \\
\hline Farmer & 100.0 & 99.0 & 0.0 & 0.1 & 0.0 & 0.0 & 0.0 & 0.0 & 0.0 & 0.0 & 0.9 \\
\hline Manager & 100.0 & 0.7 & 0.4 & 3.8 & 12.0 & 5.2 & 55.4 & 6.4 & 7.6 & 5.5 & 2.9 \\
\hline Clerical & 100.0 & 0.3 & 0.3 & 3.1 & 25.8 & 14.2 & 14.1 & 9.5 & 8.2 & 17.7 & 6.8 \\
\hline Sales & 100.0 & 0.1 & 0.0 & 0.2 & 14.8 & 0.8 & 65.1 & 13.5 & 1.7 & 0.1 & 3.9 \\
\hline Craft & 100.0 & 0.4 & 1.6 & 30.8 & 34.9 & 11.0 & 5.8 & 0.2 & 11.2 & 1.0 & 3.1 \\
\hline Operative & 100.0 & 0.8 & 11.9 & 3.8 & 47.9 & 13.3 & 13.9 & 0.1 & 4.9 & 0.2 & 3.1 \\
\hline Service & 100.0 & 0.3 & 0.1 & 1.4 & 5.9 & 3.2 & 24.7 & 5.3 & 43.8 & 11.7 & 3.5 \\
\hline Farm Laborer & 100.0 & 98.6 & 0.0 & 0.1 & 0.0 & 0.0 & 0.0 & 0.0 & 0.0 & 0.0 & 1.3 \\
\hline Non-Farm Laborer & 100.0 & 4.9 & 0.0 & 39.9 & 30.6 & 9.0 & 3.9 & 0.3 & 2.7 & 0.4 & 8.1 \\
\hline Military & 100.0 & 0.0 & 0.0 & 0.0 & 0.0 & 0.0 & 0.0 & 0.0 & 0.2 & 98.9 & 0.8 \\
\hline No Occupation & 100.0 & 0.0 & 0.0 & 0.0 & 0.0 & 0.0 & 0.0 & 0.0 & 0.0 & 0.0 & 100.0 \\
\hline
\end{tabular}

Notes: The table reports the fraction of each industry within ten broad occupation groups. "No Occupation" refers to individuals who do not work in a specific industry or where information on industry was not reported. The underlying population includes male, working age (16-65) individuals. 